\title{
Physical Disabilities:
}

\section{Education and \\ Related Services}

Keeping Our Students Safe During School Crises: Individual Emergency and Lockdown Plans for Students with Significant Disabilities

Dusty Columbia, Laura S Clarke, Kimberly Weber pp. 1-9

Under-Identification of Students with Long Term Disability from Moderate to Severe TBI: Analysis of Causes and Potential Remedies Drew A Nagele, Stephen R. Hooper, Kristin Hildebrant, Melissa McCart, Judy Dettmer, Ann

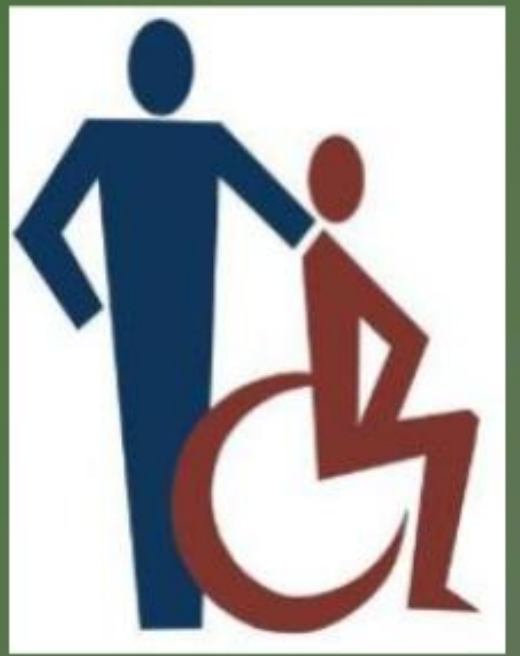
Glang pp. 10-25

Students with Acquired Brain Injury: A Legal Update

Perry A. Zirkel

pp. $26-44$

Copyright Division for Physical, Health and Multiple Disabilities 
Physical Disabilities: Education and Related Services, 2019, 38(1), 1-9.

doi: 10.14434/pders.v38i1.27970

(C) Division for Physical, Health and Multiple Disabilities

PDERS

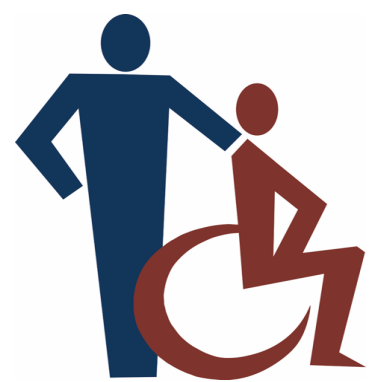

ISSN: 2372-451X

http://scholarworks.iu.edu/journals/index.php/pders/index

Article

\title{
KEEPING OUR STUDENTS SAFE DURING CRISIS
}

\author{
Dusty Columbia Embury and Laura S. Clarke
}

Wright State University

\author{
Kim Weber \\ Campbell County Public Schools
}

\begin{abstract}
As educators and parents of children with disabilities, we recognize that students with significant disabilities benefit from research-based strategies to support the development of academic and social learning. We regularly use systematic instruction and behavior supports to provide day-to-day instruction, yet this same detailed planning is not always carried through to support these students in preparation for school crises. Whether a student with a significant disability is in a weather-related event such as a tornado or a larger crisis such as a school shooting, she or he likely needs intensive instruction with research-based strategies in order to survive. In this article, we discuss the critical issue of systematically inquiring about the specific needs of students with significant disabilities as they pertain to staying safe in school crises and introduce why and how to write an Individual Emergency and Lockdown Plan (IELP) for these students.
\end{abstract}

Keywords: school safety, individualized emergency and lockdown plan, crisis, school shooting, shelter in place, evacuation, crisis plan

\section{Introduction}

A crisis in our schools can occur at any time and natural disasters such as wildfires, tornadoes, hurricanes, or earthquakes can strike with limited or no warning. In times of increased violence in schools and little or slow change in legislation regarding access to guns and support for mental health, teachers, students, parents, and communities live with increased levels of stress and fear 
for the safety of students and other personnel in schools. The crises in our schools vary in magnitude and cause, and for this reason, preparation is the key to survival for our students, teachers, and staff.

Increased drills and practices in schools may lessen some fears of many students, teachers, and communities; however, teachers and families of students with significant disabilities face greater challenges in the event of a crisis in school. Not all students have the skills to stay safe independently during a crisis. Additionally, teachers and Individualized Education Program (IEP) teams do not systematically consider this in their annual reviews and planning. In every situation, the teams that support students with significant disabilities need to plan for differences across domains such as physical abilities, receptive and expressive communication, social emotional, and cognitive abilities. Evaluating strengths and needs of students with significant disabilities as they relate to staying safe in the event of a crisis must become a part of the annual IEP process. For students whose crisis related skill levels are not commensurate with peers, a detailed plan for staying safe, for teaching the skills to be safe, and monitoring progress through instruction and opportunities for practicing those skills must be developed and implemented in order to give students the best chance of survival in the event of a school crisis (Clarke, Columbia Embury, Jones, Yssel, 2014).

This article is a call to parents, educators, and advocates to ensure that our IEP teams address crisis related skills in the annual review process by, a) assessing crisis related skills of the student at each annual review meeting and b) designing and implementing Individualized Emergency Lockdown Plans (IELP) (Clarke et al., 2014) for students who would need specially designed instruction to learn and implement crisis related skills. This article also provides specific guidance in understanding the need for, designing, and implementing Individualized Emergency Lockdown Plans (Clarke et al., 2014) for students with significant disabilities, recognizing the diverse range of developmental, intellectual, social, emotional, and physical needs of students with disabilities.

\section{Planning for Safety}

Policy, practice, and research demonstrates a need for more inclusive, thorough, and universal emergency plans, but individuals with disabilities, families, and educational professionals must advocate for and develop plans that will keep all students with significant disabilities safe in the event of a school crisis. At this time, a national model for school safety and emergency preparedness has not been implemented and existing district plans may not be adequate to keep all students in their schools safe (Chung, Danielson, \& Shannon, 2008).

Without consensus or collaboration across schools, districts, and the country, teachers, administrators, parents, students, and other community members are left to create plans to keep students safe. For students already identified as at-risk in the event of a life-threatening natural disasters or school intruder emergency, it is imperative that plans take into account the need for 
modifications and specially designed instruction for students (Boon et al., 2011; Boon, Pagliano, Brown, \& Tsey, 2012).

The current lack of national model for preparedness for school-based emergencies means that school districts can have an inadequate emergency preparedness program, or may lack a specific preparedness program entirely (Chung et al., 2008). Recent school shootings are a strong reminder that current schoolwide procedures and emergency plans must be reviewed and likely need to be revised to meet the needs of individual students with significant disabilities who may need significant support to follow or implement school safety procedures in the event of an emergency evacuation or lockdown (Boon et al., 2011). Some students may be physically unable to follow safety procedures, such as assuming a specific safety position on the floor or quickly exiting down a flight of stairs. Emergency situations require students to watch, listen, and process information likely to be unfamiliar or infrequent to them such as the sounds of gunshots, voices of intruders or safety officers. Actively problem solving during a crisis may be a difficult task for a student with a significant disability, therefore, planned and purposeful programming around crisis planning is critical for these students.

For many students, their ability to understand the sensory information (what is being said, visual signals, verbal alarms, physical sounds of danger such as gunfire or a natural disaster, etc.) is impaired or not present. Teachers must plan for students with significant disabilities to learn to recognize the sounds of danger and understand what next steps must happen in order to stay safe (Clarke et al., 2014). The importance of teaching students the specific language of emergencies in school must also be recognized and addressed (Minnesota School Safety Center, 2011). The terminology used in schools vary widely when referring to lockdowns or other emergency procedures (DHS, 2010). Schools may refer to sheltering in place, a lock-in, or even codes such as level 1 lockdown or code yellow lockdown to convey to the school community that a threat or danger is that danger is happening. Students and staff, in order to survive a crisis, must understand the language used to direct students to either seek shelter in a classroom or evacuating a building.

Because school-wide and district general emergency plans may not take into account individual learning needs, physical differences, medical, or emotional needs of individual students, students with significant disabilities are at an even greater risk in the event of a serious emergency at school (Boon et al., 2011; Boon et al., 2012). Planning specifically for the physical needs of students with disabilities affecting sensory, mobility needs, and for the instructional needs of students that need support with processing information and/or following single or multi-step directions becomes an imperative for IEP teams in an increasingly crisis-saturated world.

\section{Who Needs an Individual Emergency and Lockdown Plan?}


Students with significant physiologic (e.g., breathing rate and skin permeability) or developmental needs (e.g., communication skills and self-preservation instincts) cause some children to be more vulnerable in the event of a natural disaster or crisis (Chung et al., 2008). The IEP team including parents/families, general education teachers, administrators, related service personnel and special education teachers should consider adding a question addressing emergency safety for the student during each Individualized Education Program (IEP) meeting. We recommend using specific language: "Is there a need for a specific plan for this student if there were a crisis in the building?" (p.2, Clarke et al., 2014). When the IEP team answers "yes" to this question, an Individual Emergency and Lockdown Plan (IELP) that takes into consideration the diverse range of intellectual, social, emotional, and physical development among children with disabilities, must be created (Clarke et al., 2014).

\section{Components of the IELP}

The IELP is an individualized plan that addresses the unique strengths and needs of individual students with disabilities with regard to the skills needed to survive a life-threatening crisis in school. The IELP is made up of the following components:

1. Student information (age, grade, disability eligibility category)

2. Medical needs

3. Communication needs

4. Sensory needs

5. Other critical information

6. Specific supports or skills needed for both evacuation and shelter in place emergencies

The special education teacher must work together with the rest of the IEP team to plan for the safety of students with a disability during a lockdown or natural disaster. The IEP team understands the intellectual, physical, emotional, and health needs of students with significant disabilities and as a result, this team is best suited to design and realize the Individual Emergency Lockdown Plan (IELP) (Clarke et al., 2014). The interdisciplinary IEP team made up of special and general educators, administrators, related service providers, parent or guardians, the student, and others should also consider consulting with first responders, nursing staff, school social workers, or other personnel who may be in a situation to protect or assist a student in the event of a crisis at school when designing an IELP. Teachers should also, when appropriate, invite the student to share concerns or ideas about supports they would need in a crisis. For example, a student who uses oxygen might require additional tubing and supplies while a student with autism might need specific social narratives and "first, then" choices specific to a shelter in place or evacuation requirement. A student that requires specific positioning supports would need equipment in any room where the student engages in learning, and a student who requires medications or food at specific times of the day would need those items with him or her, as it is not possible to leave a shelter in place or evacuation to retrieve required and lifesaving supplies. 
As with any plan, the IELP is effective only if school personnel are prepared to correctly implement it at a moment's notice. It is crucial that all IELPs be discussed and practiced by all possible support personnel within a given school or facility. Ensuring that plans and emergency supplies are easily understandable and in a place that everyone can access them is crucial. This is especially important when a substitute teacher or instructional assistant is part of the student's day. For students who engage in learning in more than one classroom, every teacher and room needs to be ready to provide needed supports should a shelter in place order be given (Clarke et al., 2014).

In developing an IELP, the team should focus on the individual's strengths and needs in order to create a strength-based plans that will safely and effectively support students with disabilities in the event of an actual crisis (Edwards, Mumford, Shillingford, \& Serra-Roldan, 2007). The IELP offers an opportunity for teams to identify necessary accommodations for students as well as specific concerns that may arise for students in following directions and responding to new, dangerous, or frightening situations (Clarke et al., 2014).

\section{Development of the IELP: A data driven process}

The development of an IELP should follow the same steps teachers follow to develop an IEP. The first step is to assess student strengths in each domain. This should include the student's unique strengths and needs related to their ability to acquire skills (academic performance and cognitive functioning), current functional skills, communication style (and any communication supports such as an iPad with the Proloquo communication app). It should also address the student's current social/ emotional strengths and needs, including their ability to identify and communicate about events that are causing them distress. In addition, the student's ability to hear and/or see alarms, warning lights, or dangerous events (e.g. person with weapon, debris falling from a weather event) must be taken into account. Finally, the plan must include a student's current motor abilities, health, hearing, and vision as it relates to responding to crisis events. For example, could they shelter in place, go without medications or medical supplies for any length of time, position to the floor or in a small place, etc? Teachers may find it helpful to begin by using the Checklist in Table 1.

Table 1. Teacher IELP Checklist

\section{IELP Checklist}

\begin{tabular}{|ll|l|}
\hline Yes & $\begin{array}{l}\text { Does } \\
\text { Not } \\
\text { Apply }\end{array}$ & $\begin{array}{l}\text { After the team has created an IELP, this checklist can serve as a final } \\
\text { check to ensure the IELP meets the needs of the student. }\end{array}$ \\
\hline
\end{tabular}




\begin{tabular}{|c|c|}
\hline & $\begin{array}{l}\text { Does the IELP created for the student address mobility or other } \\
\text { physical needs? Have accommodations been made to safely evacuate or } \\
\text { shelter in place if necessary? }\end{array}$ \\
\hline & $\begin{array}{l}\text { Does the IELP address medication needs? How and when medication } \\
\text { will be secured and administered in the event of an emergency? }\end{array}$ \\
\hline & $\begin{array}{l}\text { Does the IELP addressed sensory needs? Are sensory items kept in } \\
\text { the classroom, student pack, etc.? }\end{array}$ \\
\hline & $\begin{array}{l}\text { Does the IELP address communication needs? Is there a } \\
\text { communication board, PECs cards, or other communication method } \\
\text { available? }\end{array}$ \\
\hline & $\begin{array}{l}\text { Does the IELP address emotional and/or behavior needs? What tools } \\
\text { are needed or going to be implemented? }\end{array}$ \\
\hline & $\begin{array}{l}\text { Is the student able to explain her or his IELP and/or what she or he } \\
\text { may need in a crisis? If not, how will the team address this? }\end{array}$ \\
\hline & $\begin{array}{l}\text { Have all teachers and paraprofessionals working with the student } \\
\text { reviewed the IELP? If the student requires the support of an adult to } \\
\text { evacuate or shelter in place, have all teachers and paraprofessionals who } \\
\text { may work with the student been trained on how to support the student in } \\
\text { a crisis? }\end{array}$ \\
\hline
\end{tabular}

CDusty Columbia Embury and Laura Clarke, 2019

As in the IEP process, teachers must collect relevant data in pertinent areas. Data should be collected to support a student through a multiple-hour lockdown or crisis, so the overarching question should be: What does this student need to be safe during an emergency in my school? Given this question, teachers should collect relevant information that can be used to develop the IELP. In developing an IELP, a team-centered approach is preferable. The IELP team can include some of the same people who are on the IEP team, including parents, the student, teachers who know the student, and therapists. Other key individuals who should be considered for team membership include the school nurse, counselor, behavior therapist, local medical and rescue personnel. The team should include individuals who can speak to each specific need of the student and provide suggestions for helping keep that student safe.

After the student's strengths and needs have been established, the IELP should be developed and shared the student, adults who come into contact with the student, and the student's family. The team will develop an emergency kit which should, at a minimum, include a copy of the IELP and should be with the student at all times. 


\section{Implementing the IELP}

To implement the IELP, the team should plan for regular (at least annual) review of the plan and provide as many practice opportunities as the student and/or student's team needs to be successful. Evidence-based instructional strategies should be used for specific skill instruction (e.g., waiting, staying quiet,), practice should occur across all school settings and any off-campus settings (including transportation as applicable), and changes to the plan are made as a result of student performance. progress data should be collected and analyzed.

Many students with significant disabilities have limited working memory, struggle to independently complete complex tasks, are more distracted/ forgetful and need more redirection than peers (Smith, Saez, \& Doabler, 2016). To support these specific learning needs, instruction and new information should be presented one skill at a time or with small amounts of content and practice opportunities after each skill. Explicit and systematic instruction that includes clear adult explanations, modeling, multiple examples and practice opportunities, and immediate feedback are recommended teaching strategies (Smith et al., 2016). In addition, the plan should take into account the student's unique academic, behavioral, physical, medical, social, and emotional needs. For example, many plans help the student survive the immediate crisis but do not take into account the student's very significant needs related to managing any trauma aftereffects that a student might experience after surviving a school crisis. In an effort for crisis plans to have the greatest impact, it is recommended that the student's needs before, during, and after any potential crisis are thoroughly discussed and recorded.

Preventive interventions such as teaching students how to respond during a crisis should include the establishment of specific expectations, teaching explicit expectations, and reinforcing established and taught expectations. Effective instructional strategies such as frequent comprehension checks, provide additional wait time during instruction, use of social stories and visual supports (Nagro, Hooks, Fraser, \& Cornelius, 2016), are the same strategies teachers can use to teach and assess crisis related skills.

Teachers should set reasonable goals that take into account the reality that many students have significant deficits in working memory that often limit student responses to instruction. To support this deficit, instruction should target specific skills. Through strategies including forward and backward chaining and direct instruction with modeling, teachers can support student mastery within the scope and sequence of needed lifesaving skills. As with all instruction for students with significant disabilities, the goal for instruction should be to increase independence. The key to instruction of the components of each students' IELP is to set meaningful, measurable goals that will work towards ensuring the student is safe. It is important to note that changing practices around IEP development certainly takes time. Another option for planning and outlining crisis procedures for a student could be documented in a student's meeting notes. 
To support acquisition of skills, teachers should collect and analyze data to guide instruction and adaptations to interventions. Great IELPs will involve service providers and family members in additional opportunities for learning once initial instruction has been implemented by Special Education teacher (Lemons, Allor, Otaiba, \& LeJeune, 2016). Many classrooms that support students with significant disabilities incorporate instructional assistants in the teaching of skills. For instruction to be conducted successfully by instructional assistants, teachers should provide specific training in the instructional practice, complete fidelity checks, and give performance feedback (Brock, Seaman, \& Downing, 2017). With any IELP that requires instruction, teachers should follow the principles of high-quality practices which include data collection and analysis to monitor student progress and determine needed intensity of the intervention.

\section{Final Thoughts}

When looking at considerations that can impact the safety of a student with significant a disability, families, students, and advocates must work together with school teams to routinely consider the crisis-related skills needed to stay safe in a school crisis; whether or not students have those skills; and to design and implement a plan to teach those skills when needed. We must plan for the best way to support individual students with disabilities in a crisis situation and developing and implementing an IELP may be critical for the safety of some students with significant disabilities. Whether a student experiences a weather-related event or human-made crisis, the adults supporting that student need to have a clearly developed plan that they practiced, taught to the student, and continue to keep current so everyone has the best chance to go home safe every day. 


\section{References}

Boon, H. J., Brown, L. H., Tsey, K., Speare, R., Pagliano, P., Usher, K., \& Clark, B. (2011). School disaster planning for children with disabilities: A critical review of the literature. International Journal of Special Education, 26, 1-14. Retrieved from http://www.internationalsped.com/.

Boon, H. J., Pagliano, P., Brown III, L., \& Tsey, K. (2012). An Assessment of Policies Guiding School Emergency Disaster Management for Students With Disabilities in Australia. Journal of Policy and Practice in Intellectual Disabilities, 9(1), 17-26. https://doi.org/10.1111/j.1741-1130.2012.00331.x

Brock, M. E., Seaman, R. L., \& Downing, C. (2017). Promoting learning for a student with a severe disability through paraprofessional training. Research and Practice for Person with Severe Disabilities, 42(2), 211-224. https://doi.org/10.1177/1540796917729682

Chung, S., Danielson, J., \& Shannon, M. (2008). School-based emergency preparedness: A recommended protocol. Rockville, MD: Agency for Healthcare and Quality. Retrieved from https://archive.ahrq.gov/prep/schoolprep/.

Clarke, L. S., Embury, D. C., Jones, R. E., \& Yssel, N. (2014). Supporting Students With Disabilities During School Crises: A Teacher's Guide. TEACHING Exceptional Children, 46(6), 169-178. https://doi.org/10.1177/0040059914534616

Department of Homeland Security. (2010) National Incident Management System. Plain Language Frequently Asked Questions. DHS, June 2010. Retreived from www.dhs.gov.

Edwards, O. W., Mumford, V. E., Shillingford, M. A., \& Serra-Roldan, R. (2007).

Developmental assets: A prevention framework for students considered at risk. ProQuest Nursing \& Allied Health Source, 29, 145-154. doi:10.1093/cs/29.3.145

Lemons, C.J., Allor, J. H., Al Otaiba, S. \& LeJeune, L. M. (2016.) 10 research-based tips for enhancing literacy instruction for students with intellectual disability. TEACHING Exceptional Children, 49 (1), 18-30. doi:10.1177/0040059916662202

Minnesota School Safety Center. (2011). Comprehensive school safety guide: Minnesota School Safety Center program. Retrieved from https://dps.mn.gov/ divisions/hsem/mn-schoolsafety-center/ Documents/2011\%20Comprehensive\%20 School\%20Safety\%20Guide.pdf

Nagro, S. A., Hooks, S. D., Fraser, D. W. \& Cornelius, K. E. (2016). Whole-group response 
Physical Disabilities: Education and Related Services, 38(1)

strategies to promote student engagement in inclusive classrooms. TEACHING

Exceptional Children, 48, 243-249. https://doi.org/10.1177/0040059916640749

Smith, J. L., Saez, L., \& Doabler, C. T. (2016). Using explicit and systematic instruction to support working memory. TEACHING Exceptional Children, 48, 275-281. https://doi.org/10.1177/0040059916650633

Authors' note: Address correspondence concerning this article to Dusty Columbia Embury at dusty.columbia@wright.edu. 
Physical Disabilities: Education and Related Services, 2019, 38(1), 10-25. doi: 10.14434/pders.v38i1.26850

(C) Division for Physical, Health and Multiple Disabilities

PDERS

ISSN: $2372-451 X$

http://scholarworks.iu.edu/journals/index.php/pders/index

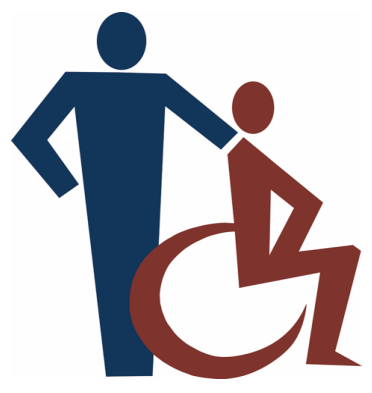

Article

\title{
UNDER IDENTIFICATION OF STUDENTS WITH LONG TERM DISABILITY FROM MODERATE TO SEVERE TBI: ANALYSIS OF CAUSES AND POTENTIAL REMEDIES
}

\section{Drew A. Nagele}

Philadelphia College of Osteopathic Medicine

\section{Stephen R. Hooper}

University of North Carolina-Chapel Hill

\section{Kristin Hildebrant}

Disability Rights Ohio, Columbus, Ohio, 43215;

\section{Melissa McCart}

Center on Brain Injury Research and Training, University of Oregon

\section{Judy L. Dettmer}

MINDSOURCE - Brain Injury Network, Colorado Department of Human Services

\section{Ann Glang}

Center on Brain Injury Research and Training, University of Oregon

\begin{abstract}
Traumatic brain injury (TBI) has historically been considered a low-incidence disability in public education, and yet estimates indicate that nearly 145,000 children in the United States aged 0-19 are currently living with long-lasting, significant alterations in social, behavioral, physical, and cognitive functioning from a TBI. Comparing this number with the total number of students receiving special education services under the TBI eligibility category found only 26,371 students across all grades. Thus, it appears that a large number of students with significant disability following TBI are not being served under the TBI category, and raises the possibility that many students are not being identified and/or effectively served by educational practitioners in the public-school system. This paper examined the discrepancy between the number of students expected to experience disability using hospitalization data for
\end{abstract}


moderate-severe TBI and the number of students who receive special education services under the TBI eligibility category.

On average, the number of students actually identified nationally under the Special Education TBI category is only $32 \%$ of the students who have moderate-severe TBI across the country. Possible reasons for this discrepancy are explored, including lack of awareness about TBI as a disability, lack of communication between hospital and school, under-reporting of injuries by parents, a narrow definition of TBI that excludes other forms of acquired brain injury, and students with TBI receiving services under alternate disability categories. Recommendations are offered for providing staff training on brain injury, increasing parent awareness of TBI, increasing identification of brain injury in students through screening, and program evaluation of school brain injury protocols.

\section{Acknowledgements:}

The authors acknowledge the Members of the National Collaborative on Brain Injury (NCCBI) for their review/feedback of this manuscript, and Dr. John Corrigan of Ohio State University and Dr. Julie Daniels of University of North Carolina Gillings School of Global Public Health for their consultations on methodology.

\section{Introduction}

Although traumatic brain injury (TBI) is considered a low-incidence disability in public education, it is actually a high incidence medical event. National estimates indicate that nearly 145,000 children aged 0-19 are currently living with long-lasting, significant alterations in social, behavioral, physical, and cognitive functioning following a TBI (Zaloshnja, Miller, Langlois, \& Selassie, 2008). However, in 2013, the total number of students receiving special education services under the TBI eligibility category was only 26,371 (U.S. Department of Education, 2013), raising concerns that a large number of students with significant disability following TBI are not being served under the TBI category. This discrepancy is worrisome given the extent of learning and behavioral challenges many students with moderate to severe TBI experience. This raises the possibility that many students are not being identified and/or effectively served by educational practitioners in the public-school system.

Children with TBI who return to school with significantly altered learning abilities present unique challenges for educators. Challenges with memory, executive function, attention, concentration, and processing speed can negatively affect a child's ability to learn and perform in school (Ewing-Cobbs, Prasad, \& Kramer, 2006; Prasad, Swank, \& Ewing-Cobbs, 2017; GerrardMorris, Taylor, Yeates, 2010; Hawley, 2004; Moser, Schatz, \& Jordan, 2005). Behavioral challenges, impulsivity, and emotional issues are also common after TBI (Barlow et al., 2010; Li, \& Liu, 2013; Limond, Dorris, \& McMillan, 2009; Ryan et al., 2016) and can negatively 
affect school performance, perhaps as long as ten years post-injury (Beauchamp et al., 2011). Following TBI, children experience persistent lower life satisfaction, reduced adaptive functioning, and lower rates of participation in a variety of activities compared with children who have orthopedic injuries, and those differences can persist throughout their formal schooling (Rivara, Koepsell, \& Wang, 2012a; Rivara, Vavilala, \& Durbin, 2012b). Children with moderate to severe brain injury often experience increasingly severe challenges over time that intensifies the need for academic and behavioral interventions (Beauchamp et al., 2011; Gerrard-Morris, Taylor, \& Yeates, 2010; Kurowski et al., 2011; Yeates, Armstrong, \& Janusz, 2005). In addition, the long-term effects of lasting mild TBI can result in significant academic deficits over time because of the potential impact of brain injury on students' acquisition of new learning (Prasad et al., 2017). Most children who are hospitalized for TBI are sent directly home from acute medical treatment. Of children hospitalized for TBI, 3.7\% receive inpatient rehabilitation (Greene, Kernic, Vavilala, \& Rivara, 2014). Students who experience TBI may return to school with physical, cognitive and behavioral deficits that significantly impact their educational performance. Therefore, it is critical for school teams to correctly identify, track, and serve students with TBI.

\section{Why Is It Important to Identify Students with TBI for Special Education Services?}

For students with significant deficits following brain injury, identification for special education is an essential first step to accessing appropriate educational services. The Individuals with Disabilities Education Act (IDEA) defines TBI as:

an acquired injury to the brain caused by an external physical force, resulting in total or partial functional disability or psychosocial impairment, or both, that adversely affects a child's educational performance. Traumatic brain injury applies to open or closed head injuries resulting in impairments in one or more areas, such as cognition; language; memory; attention; reasoning; abstract thinking; judgment; problem-solving; sensory, perceptual, and motor abilities; psycho-social behavior; physical functions; information processing; and speech. The term does not apply to brain injuries that are congenital or degenerative, or to brain injuries induced by birth trauma. (20 U.S.C. Sec. 1401 [2004], 34 C.F.R. Sec. $300.8[\mathrm{c}][12])$

Most states require medical documentation of an event that was likely to have caused a TBI in order for students to be found eligible for TBI under IDEA. Assessments must show a difference between the student's pre-injury and post-injury performance and demonstrate a need for specially designed instruction for the student to benefit from the educational environment. Identifying a student as eligible under the TBI category does not guarantee the provision of specially designed instruction and related services. However, school teams often do not receive the information and training needed to understand the nature of the injury and to help tailor educational services to the student's specific needs (Todis, Glang, \& Fabry, 1997). This lack of 
understanding can result in students receiving fewer or inappropriate services that might not meet their individual needs (Todis \& Glang, 2008).

The primary purpose of this paper is to examine the discrepancy between the number of students expected to experience disability following hospitalization for moderate-severe TBI and the number of students who receive special education services under the TBI eligibility category, and to explore potential explanations for this discrepancy. Moderate to severe TBI is defined as a brain injury with either normal or abnormal structural imaging, with a loss of consciousness greater than 30 minutes, post traumatic amnesia greater than one day, and a Glasgow Coma Scale score of 12 or less out of 15 (Abashian \& Reyst, 2016). Based on analysis of data for the most current year (i.e., 2013) when both TBI hospitalization data and TBI special education classification data were available, we anticipated that there would be a significant discrepancy between those students receiving services under the TBI classification versus those students with moderate to severe brain injury. Other student populations, such as those with emotional/behavioral disorders, where service gaps are expected between the need for specialized educational services and actual service delivery, have been studied using similar methods (Forness, Freeman, Paparella, Kauffman, \& Walker, 2012).

\section{Methods}

To conduct an analysis of the number of students with disability following TBI with those receiving special education, we compared three sets of data from 2013, the most recent available year when state and federal sources for these specific statistics aligned. We accessed statereported statistics on the number of students identified for special education under the TBI category in 2013 and obtained each state's population statistics for that year from US Census data for age groups from 5-24. By comparing the census figures with the Centers for Disease Control (CDC) estimates of national TBI hospitalizations, we derived an estimated hospitalization incidence for moderate to severe brain injury for each state. To be conservative in constructing estimates of the number of students likely to be eligible for special education services under the TBI category, we included only those students with moderate to severe TBI who would likely have a disability substantial enough to require special education services and therefore expected to be eligible under the classification of TBI under IDEA. To do this, we utilized the definition of mild TBI and moderate-severe TBI criteria from the National Center for Injury Prevention and Control (2003). The only state that has studied their hospitalization data using these criteria is Ohio, so we applied these criteria to actual 2014 TBI hospitalization data in Ohio to calculate a rate of hospitalization for moderate-severe TBI by age group (Ohio Brain Injury Program, 2018). These data indicated that for the age group 5-14, 40.9 percent of TBI hospitalizations met the criteria of moderate to severe, and for the age group 15-19, 34.5 percent of TBI hospitalizations met the criteria of moderate to severe. 
To get from incidence to prevalence, we multiplied the incidence data times a weighted average of the number of school cohorts from kindergarten through 12th grade and the degree to which any cohort in those 13 years could contribute to prevalence over a 13-year period (see Table 1 below). Thus, the multi-year cohort factor used to determine a prevalence estimate for any given year is 6.5 , assuming an average contribution of ages in any given year.

Table 1

\section{Prevalence Calculations for Degree to Which Any Cohort in 13 Years Could Contribute to}

Prevalence in a Given Year

\begin{tabular}{ccc}
\hline $\begin{array}{c}\text { If a student was } \\
\text { this age when } \\
\text { injured }\end{array}$ & $\begin{array}{c}\text { Then they could be counted in Spec Ed } \\
\text { TBI Count for this \# of years if } \\
\text { graduating at age 18 }\end{array}$ & $\begin{array}{c}\text { Average Contribution to any 1 } \\
\text { year of Cohort }\end{array}$ \\
\hline 5 & 12.5 & 0.96 \\
6 & 11.5 & 0.88 \\
7 & 10.5 & 0.81 \\
8 & 9.5 & 0.73 \\
9 & 8.5 & 0.65 \\
10 & 7.5 & 0.58 \\
11 & 6.5 & 0.50 \\
12 & 5.5 & 0.42 \\
13 & 4.5 & 0.35 \\
14 & 3.5 & 0.27 \\
15 & 2.5 & 0.19 \\
16 & 1.5 & 0.12 \\
17 & 0.5 & 0.04 \\
18 & 0.0 & 0.00 \\
\hline
\end{tabular}

Average

6.50

Weighting

We then compared that adjusted number of students living with moderate to severe TBI in the year 2013 in each state with the number of students identified under the TBI category in the year 2013 in each state. These procedures produced an estimate that represents the percentage of students presumed to have moderate to severe TBI who are counted in existing state special education TBI categories.

\section{Results}

Only one state, Massachusetts, met or exceeded the expected numbers of students identified for services under a TBI eligibility based on our analysis. Massachusetts had 8,875 students identified under the TBI category, which far exceeds what would be projected using our model. This is because Massachusetts uses a different, more expansive definition for its TBI category that includes students with any type of neurological disability: 
Neurological Impairment - The capacity of the nervous system is limited or impaired with difficulties exhibited in one or more of the following areas: the use of memory, the control and use of cognitive functioning, sensory and motor skills, speech, language, organizational skills, information processing, affect, social skills, or basic life functions. The term includes students who have received a traumatic brain injury (Massachusetts Department of Elementary and Special Education, 2018).

In fact, according to a review by the National Association of State Head Injury Administrators (Vaughn, 2014) five additional states by that time had begun including some other types of acquired brain injury into their TBI category (New York, North Carolina, Ohio, Vermont, and Wisconsin). Because these six states had begun including both TBI per the federal definition (external force) and other forms of non-traumatic brain injuries (cancer, hypoxia, drug overdose), these six states were excluded from the rest of the national comparison.

Table 2 illustrates that the majority of the other 44 states significantly under-identify students with moderate to severe TBI who would be expected to meet the criteria for special education under IDEA. The total number of students identified nationally was 14,102. Based on our estimates as noted above, we would expect there to have been 44,597 students identified as TBI. On average, the number of students actually identified nationally in the 44 states under the TBI Special Education category represents only $32 \%$ of the students who have moderate-severe TBI across those states. This under-identification of TBI ranged from 19\% being accurately identified in Connecticut, to $75 \%$ being accurately identified in Wyoming. Overall, we estimate that 30,495 students, or $68 \%$ of the students who should meet the IDEA definition for TBI, have not been classified appropriately.

Table 2

TBI Students Undercounted as a Percentage of Projected TBI Prevalence

\begin{tabular}{|c|c|c|c|c|c|c|c|c|c|c|c|c|}
\hline $\begin{array}{c}\text { Actual } \\
\text { Number } \\
\text { School } \\
\text { Identified } \\
\text { Prevalence } \\
\text { (IDEA, 2013) } \\
44 \text { states }^{1}\end{array}$ & $\begin{array}{c}\text { Estimated } \\
44 \text { State } \\
\text { Population } \\
\text { of } \\
\text { Individuals } \\
\text { Ages 5-9 } \\
(2013)^{2}\end{array}$ & $\begin{array}{c}\text { Estimated } \\
44 \text { State } \\
\text { Population } \\
\text { of } \\
\text { Individuals } \\
\text { Ages } 10-14 \\
(2013)^{2}\end{array}$ & $\begin{array}{c}\text { Estimated } \\
\text { 44 State } \\
\text { Population } \\
\text { of } \\
\text { Individuals } \\
\text { Ages } 15-19 \\
(2013)^{2}\end{array}$ & $\begin{array}{c}\text { CDC TBI } \\
\text { National } \\
\text { Hospital- } \\
\text { ization } \\
\text { Estimates Ages } \\
5-14=21.1 \text { per } \\
100,000 \\
(2013)^{3}\end{array}$ & $\begin{array}{c}\text { CDC TBI } \\
\text { National } \\
\text { Hospital- } \\
\text { ization } \\
\text { Estimates } \\
\text { Ages } 15-19 \\
=64.3 \text { per } \\
100,000 \\
(2013)^{3}\end{array}$ & $\begin{array}{l}\text { Estimated } \\
\text { Total Annual } \\
44 \text { State } \\
\text { Incidence } \\
\text { Students with } \\
\text { TBI } 2013\end{array}$ & $\begin{array}{c}\text { Estimated } \\
\text { Moderate to } \\
\text { Severe TBI } \\
\text { Ages 5-14 = } \\
40.9 \%{ }^{4}\end{array}$ & $\begin{array}{c}\text { Estimated } \\
\text { Moderate to } \\
\text { Severe TBI } \\
\text { Ages } 15-19= \\
34.5 \%{ }^{4}\end{array}$ & $\begin{array}{c}\text { Total } \\
1 \text { year } \\
\text { Moderate } \\
\text { to Severe } \\
\text { TBI All } \\
\text { Age } \\
\text { Students }\end{array}$ & $\begin{array}{l}\text { Estimated } \\
\text { State } \\
\text { Prevalence } \\
\text { Moderate- } \\
\text { Severe TBI = } \\
\text { Incidence X } \\
6.5 \text { (based on } \\
\text { weighting } \\
\text { Table 1) }\end{array}$ & $\begin{array}{l}\text { Number of } \\
\text { Students } \\
\text { with } \\
\text { Moderate- } \\
\text { Severe TBI } \\
\text { NOT } \\
\text { counted in } \\
\text { State TBI } \\
\text { Classifica- } \\
\text { tion }\end{array}$ & $\begin{array}{c}\text { Percent } \\
\text { Projected } \\
\text { Moderate- } \\
\text { Severe TBI } \\
\text { Population } \\
\text { Accurately } \\
\text { Classified }\end{array}$ \\
\hline 14,102 & $17,231,835$ & $17,229,402$ & $17,523,401$ & 7,271 & 11,268 & 18,539 & 2,974 & 3,887 & 6,861 & 44,597 & 30,495 & $32 \%$ \\
\hline
\end{tabular}

Note. ${ }^{1}$ U.S. Department of Education (2013); ${ }^{2}$ U.S. Census Bureau, American Fact Finder (2013); ${ }^{3}$ Taylor, Bell, Breiding, Xu, (2017); ${ }^{4}$ Ohio Brain Injury Program (2018).

Figure 1 illustrates a relative comparison of states on under-identification of brain injury. Thirteen states classified only $19 \%$ to $30 \%$ of students expected to have moderate-severe TBI under the special education category of TBI; eighteen states classified $31 \%$ to $40 \%$ of those 
students; nine states classified $41 \%$ to $50 \%$ of those students, and only four states appropriately classified $51 \%$ or more of those students. Even if the expected number of students eligible for the TBI category is over-estimated by our calculations, there remains a significant chance that the actual number of students being served under the TBI category is much smaller than the number of students who likely need such services.

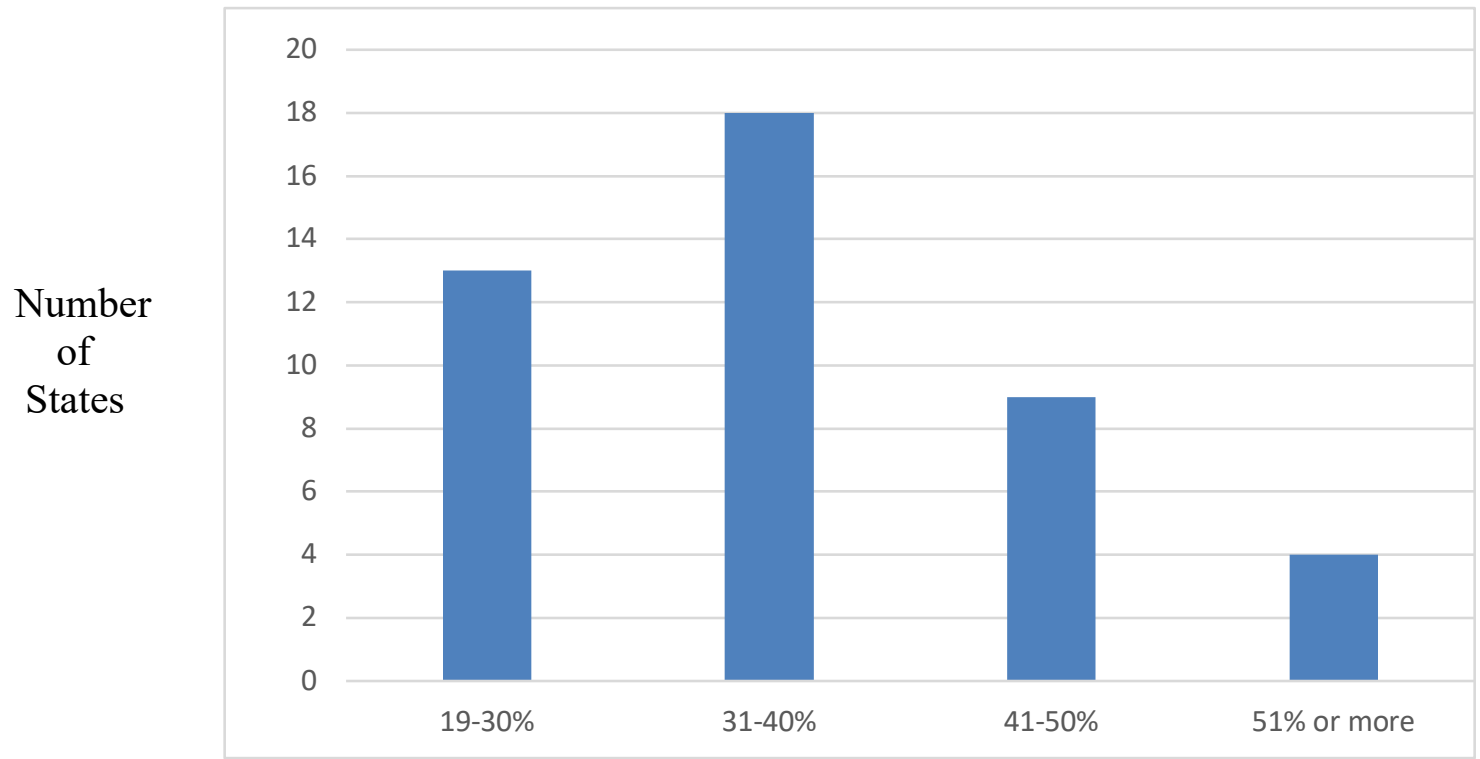

Percent of Expected Students with Brain Injury

Accurately Classified Under the TBI Category

Figure 1. Number of states classifying accurately students expected to have moderate-severe TBI under the TBI special education category.

\section{Discussion}

The purpose of this study was to examine the potential discrepancy between the number of students being identified and served under the IDEA eligibility of TBI and the projected number of students with TBI living with disability based on national hospitalization rates and disability estimates. The evidence gathered in this investigation provides the first formal evaluation of the available data to confirm the discrepancy. As expected, our analysis suggests that there are more students with moderate to severe brain injury who are likely to need special education services than who are actually receiving it.

Findings from a recent survey of State Special Education Directors provide some explanation of this striking discrepancy (Glang et al., 2015). Special Education Directors identified the following reasons for the under-identification of students with TBI: (a) lack of awareness about 
TBI as a disability, (b) lack of communication between hospital and school, (c) under-reporting of injuries by parents, and (d) a narrow definition of TBI that excludes other forms of acquired brain injury. Perhaps most importantly, sixty percent of State Directors reported students with TBI receiving services under alternate disability categories including Other Health Impaired, Specific Learning Disability, Emotional Disturbance, Intellectual Disability, and Multiple Disabilities. This is a critical point because although students with TBI might be receiving special education services under a different IDEA eligibility (Glang, et al., 2015), they likely are not receiving specially designed instruction that meets the needs of students with TBI.

The discrepancy between the number of students being served under the TBI eligibility category and the projected number of students with TBI living with long-term disability could also be attributed to inadequacies in tracking students with TBI prior to entering the special education system. The likelihood of under-identification is particularly great for children injured at a young age (Report to Congress, 2018). Like older students, these children may be identified for services under a different eligibility category. In addition, because parents and healthcare providers lack knowledge about specialized support services for young children who experience TBI they may not make referrals at the time of injury.

It also is possible that students with moderate to severe TBI end up in other settings, such as private schools or juvenile justice programs, secondary to other factors such as severe behavioral difficulties or legal involvement. Further, Prasad et al. (2017) suggest that students often "grow into their disability," experiencing more challenges as expectations increase as they age. Each of these factors could contribute to the lower numbers of students identified in the eligibility category of TBI for nearly all states.

\section{Implications for Practice and Policy}

Provide staff training on brain injury. The first step for proper identification of students with TBI is increasing awareness among school staff about TBI and its effects on children in the school setting (Todis, McCart, M., \& Glang, A., 2018). Schools can raise general awareness of TBI through the use of educational posters, email blasts, and other group-based methods of education. However, it is possible that even when teachers are aware of a prior TBI, they may not in later years associate new problems with an old TBI. If teachers receive brain injury training, they would be better able to identify physical changes (tiredness, headaches, lack of focus or interest, sensitivity to light or noise, etc.), cognitive changes (inability to learn new material, memory problems, organizational problems, distractibility, etc.), emotional changes (moodiness, depression, anxiety, etc.), and behavioral changes (frustration, irritability, aggression, inability to deal with normal situations, etc.). Additionally, teachers and other staff should be trained to realize that the effects of a TBI will vary from student to student, and sometimes from day to day for an individual student. Some children are misidentified as infants 
or toddlers as having a developmental delay, when in fact their challenges resulted from a brain injury. Useful information about TBI is available to educators from a variety of websites (e.g., see www.cbirt.org, www.tbi.cidd.unc.edu, www.brainline.org, www.BrainSTEPS.net, www.cokidswithbraininjury.com, www.youthbraininjury.obaverse.net, www.neuroskills.com/education-and-resources/, and http:/www.cdc.gov/headsup/ for resources to address TBI in schools).

General awareness training should focus on the potential for undiagnosed/unidentified TBI, and the associated systems and services available to address the educational needs of students with TBI. For example, the Columbus City Schools (CCS) in Ohio developed a TBI Program that includes awareness activities and designated, trained staff to help identify and serve affected children in the district. With this training, paired with a systematic screening process, plus a procedure for notifying the school that an injury has occurred, CCS significantly increased the numbers of students referred for TBI consultation, from 11 students per year at the start of the program, to an average of 166 students per year in years 4 through 7 (Davies, 2016).

For many children, the eventual effects of a TBI can emerge many years after injury or become more significant over time as the child becomes less able to meet the increasingly complex demands of higher grades (Prasad et al., 2017). To be effective, training for educators must include information about the long-term effects of TBI on learning and behavior and the impact of childhood TBI on the family. In addition, effective training includes information and practice with evidence-based interventions, and continued mentoring, feedback, and consultation in the school setting. Program development models that incorporate brain injury consultation in the school setting can help teachers feel more prepared and knowledgeable in working with students with TBI (Glang, A., Todis, Sublette, Brown, \& Vaccaro, 2010; Myers et. al 2018).

Professional development and TBI awareness programs for staff, especially regular and special education teachers, should also address the issue of alternative or misclassification of students with TBI. Professional development should include information about how a TBI differs from other educational disabilities, such as a learning disability, which tends to be stable in its effects on learning. With TBI, a child might remember what they learned before the TBI, but have difficulty learning new information after the injury. Because TBI is typically an injury acquired after birth, children often struggle with how their life has changed, leading to emotional issues that interrupt both the educational process and their capacity to develop relationships and navigate their social surroundings. Thus, a brain injury is not just a medical issue; it affects everything going forward about how a student is able to learn, grow, develop, and transition to adult roles. Training about these and other issues that affect students with TBI can help a school properly identify and serve those children.

Increase parent awareness of TBI. Parents of students should be included in any TBI 
awareness campaign. Both school staff and parents are vital participants in the early identification of students who might be eligible for special education or other accommodations. Schools can raise parental awareness of TBI through programs similar to those used in staff awareness campaigns by targeting brain injury education materials to parents. Schools can also include brain injury awareness materials in their regular procedures required under IDEA's Child Find requirements. Some children with TBI will not qualify for services under IDEA standards, but they might qualify for services under different federal laws. Any outreach to parents should include information about all applicable laws, and parents should be educated about the requirements for and availability of services via special education (i.e., individual education plans), Section 504 legislation (i.e., 504 plans), student health/accommodation plans, and other methods that include all children with TBI.

Increase identification of brain injury in students through screening. Identification of students with TBI can be improved through the use of screening procedures (Dettmer, Ettel, Glang, \& McAvoy, 2014). Typically, children are assessed for eligibility using traditional psychoeducational assessments that can miss key areas of functioning (e.g., specific forms of memory, executive dysfunctions, attention), lessening the chances of linking the sequelae of TBI to educational performance. Use of an effective screening tool followed by appropriate assessment that captures information about the effects of TBI on learning will lessen the likelihood that children with TBI remain unidentified or misidentified in school (Dettmer, et al., 2014; Minnesota DOC Intake Screening Tool, 2015).

Screening for TBI involves asking an informant (usually the parent for younger children; older children can answer for themselves) a series of questions designed to determine whether a child has ever received a blow to the head that might have caused a brain injury. These screening questions should be asked at least annually. Questions such as, "has your child ever been involved in a motor vehicle crash?" or "has your child ever had a concussion, been knocked out, or lost consciousness?" then trigger follow-up questions or assessments to determine whether the child should be evaluated for a TBI. Several screening tools have been developed that schools can use as part of a program to better identify and serve students with TBI. One such tool is the OSU TBI-ID screening tool available at no cost at http://ohiovalley.org/tbi-id-method/ (Corrigan \& Bogner, 2009). It is based on the CDC's framework to provide a systematic identification method. Because any screening method contains the potential for errors (i.e., false positives and false negatives), we recommend using a tool that has been validated for this purpose. The Columbus, Ohio City Schools developed their own screening tool that asks questions to determine whether a child might have experienced a TBI (Davies, 2016). If the screen suggests that a child might have experienced a TBI, further assessment is conducted, followed by special education or accommodations for eligible students. Other available screening tools include the Brain Check Survey (see http://www.lobi.chhs.colostate.edu/survey.aspx) (Dettmer, Daunhauer, 
Detmar-Hanna, \& Sample, 2007) and the Brain Injury Screening Questionnaire (Cantor, et al., 2004).

After implementation of a screening process, schools should establish a protocol for connecting children flagged by the screening tool to school and medical/rehabilitation systems that can address the learning problems caused by the TBI. That protocol should consider the types of referral, the referral process, the need for assessments, and all available sources of support. Children who have a TBI can be eligible for a variety of services and supports, including special education, classroom accommodations, behavior support plans, health plans, and return to play (student athletes) supports.

Several challenges in screening children and adolescents for TBI should be noted. Because there is considerable symptom overlap between TBI and other disabilities (eg, executive functionrelated disabilities, learning disabilities), a screening measure may lack adequate specificity with regard to TBI (Iverson, Langlois, McCrea, \& Kelly, 2009, Schwab et al., 2007). In addition, most studies examining efficacy of screening tools have focused on adults. Finally, screening tools cannot be used in isolation but should be integrated with a detailed evaluation of the student's skills to determine whether the TBI has resulted in functional impairment with adverse educational impact.

Program evaluation of brain injury protocols. Evaluation of programs that schools put in place to raise aware of TBI and to train teachers on TBI learning strategies is needed to ensure that protocols used by schools actually benefit students, and that information is collected to assist with refinement of protocols. Schools should ensure that data collection for program evaluation includes baseline information from before the implementation of a TBI program (number of students identified under the TBI category, child-specific educational performance prior to injury, pre-training surveys, etc.) and information from after implementation of the program (number of students identified under the TBI category, re-classification of children to the TBI category from other special education categories, post- training surveys, number of staff trained, etc.). It would also be helpful to know how many students with TBI receive 504 services, how many do well with those learning supports, and how many who start with 504 services go on to need special education services. Understanding the implications of under-identification is essential. Further, strengthening data collection about TBI in other systems, such as the juvenile justice system, mental health/psychiatric system, and drug/alcohol system, and tying those data back to school programming and supports is also essential. Those data should be reviewed annually by school professionals to facilitate the processes by which students are screened, assessed, identified, and served following a TBI.

\section{Limitations}


The primary limitations of this analysis involve the sources of data. The large discrepancies suggested between TBI hospitalization data, estimates of long-term disability caused by TBI, and the projected numbers of students who should be served under the TBI category are, in large part, based on population and disability estimates. TBI hospitalization data do not specify length of stay, making it difficult to understand injury severity of students admitted to the hospital; thus, the extrapolation of actual data from Ohio hospitalizations were used to generate projections of injury severity and subsequent extent of disability. While we acknowledge that our numbers are largely estimates, we also would note that the magnitude of the discrepancies between those being served under the TBI special education eligibility and the projected number who should be candidates for such services are very large and warrant further inquiry.

\section{Summary and Conclusion}

The discrepancy between expected and actual numbers of students being served under the special education eligibility category of TBI is puzzling at best, and the estimated magnitude of this discrepancy is worrisome. Exploring the underlying reasons for this apparently large discrepancy in the number of students who are being served via the TBI special education eligibility will likely afford an increase in the number of students who are identified following a TBI, and will contribute to systematic improvements in how the educational needs of these students and their families are met. 


\section{References}

Abashian, M. \& Reyst, H. (Eds.). (2016). The essential brain injury guide (5 ${ }^{\text {th }}$ ed.). Vienna, VA: Brain Injury Association of America.

Barlow, K. M., Crawford, S., Stevenson, A., Sandhu, S. S., Belanger, F., \& Dewey, D. (2010). Epidemiology of post-concussion syndrome in pediatric mild traumatic brain injury. Pediatrics, 126(2), e374-e381. Retrieved from www.pediatrics.org/cgi/doi/10.1542/peds.2009-0925.

Beauchamp, M., Catroppa, C., Godfrey, C., Morse S., Rosenfeld, J.V., \& Anderson, V. (2011). Selective changes in executive functioning ten years after severe childhood traumatic brain injury. Developmental Neuropsychology, 36(5), 578-595. https://doi.org/10.1080/87565641.2011.555572

Bogner, J.A., \& Corrigan, J.D. (2009). Reliability and validity of the OSU TBI identification method with prisoners. Journal of Head Trauma Rehabilitation, 24(6), 279-291. https://doi.org/10.1097/HTR.0b013e3181a66356

Cantor, J.B., Gordon, W.A., Schwartz, M.E., Charatz, H.J., Ashman, T.A., \& Abramowitz, S. (2004). Child and parent responses to a brain injury screening questionnaire. Archives of Physical Medicine \& Rehabilitation, 85(4 Suppl 2), S54-60. https://doi.org/10.1016/j.apmr.2003.08.113

Davies, S. (2016). School-based traumatic brain injury and concussion management program. Psychology in the Schools, 53(6), 567-582. https://doi.org/10.1002/pits.21927

Dettmer, J., Daunhauer, L., Detmar-Hanna, D., \& Sample, P.L. (2007). Putting brain injury on the radar: Exploratory reliability and validity analyses of the screening tool for identification of acquired brain injury in school-aged children. Journal of Head Trauma Rehabilitation, 22(6), 339-349. https://doi.org/10.1097/01.HTR.0000300229.13490.c7

Dettmer, J., Ettel, D., Glang, A., \& McAvoy, K. (2014). Building statewide infrastructure for effective educational services for students with TBI: Promising practices and recommendations. Journal of Head Trauma Rehabilitation, 29(3), 224-232. DOI:

10.1097/HTR.0b013e3182a1cd68

Ewing-Cobbs, L., Prasad, M.R., Kramer, L., Cox Jr, C.S., Baumgartner, J., Fletcher, S.,....Swank, P. (2006). Late intellectual and academic outcomes following traumatic brain injury sustained during early childhood. Journal of Neurosurgery: Pediatrics, 105(4), 287-296. https://doi.org/10.3171/ped.2006.105.4.287

Forness, S., Freeman, S., Paparella, T., Kauffman, J. \& Walker, H. (2012). Special education implications of point and cumulative prevalence for children with emotional or behavioral disorders. Journal of Emotional and Behavioral Disorders, 20(1), 4-18. https://doi.org/10.1177/1063426611401624

Gerrard-Morris, A., Taylor, H.G., \& Yeates, K.O. (2010). Cognitive development after traumatic brain injury in young children. Journal of the International Neuropsychological Society, 16(1), 157-168. https://doi.org/10.1017/S1355617709991135 
Glang, A., Ettel, D., Todis, B., Gordon, W.A., Oswald, J.M., Vaughn, S.L., \& Brown, M. (2015). Services and supports for students with traumatic brain injury: Survey of state educational agencies. Exceptionality, 23(4), 211-224. https://doi.org/10.1080/09362835.2014.986612

Glang, A., Todis, B., Sublette, P., Eagan-Brown, B., \& Vaccaro, M. (2010). Professional development in TBI for educators: The importance of context. Journal of Head Trauma Rehabilitation, 25(6), 426-432. https://doi.org/10.1097/HTR.0b013e3181fb8f45

Greene, N.H., Kernic, M. A., Vavilala, M.S., \& Rivara, F. P. (2014). Variation in pediatric traumatic brain injury outcomes in the United States. Archives of Physical Medicine and Rehabilitation, 95(6), 1148-1155. https://doi.org/10.1016/j.apmr.2014.02.020

Hawley, C. A. (2004). Behaviour and school performance after brain injury. Brain Injury, 18(7), 645-659. Retrieved from https://doi.org/10.1080/02699050310001646189.

Individuals with Disabilities Education Act of 2004, (IDEA) Pub. L. 101-476, Section 300.7. Iverson G.L, Langlois J.A, McCrea M.A, Kelly J.P. (2009). Challenges associated with postdeployment screening for mild traumatic brain injury in military personnel. Clinical Neuropsychology, 23(8), 1299-1314. https://doi.org/10.1080/13854040903153902

Journal of Head Trauma Rehabilitation, 23(6), 394-400. https://doi.org/10.1097/01.HTR.0000341435.52004.ac

Kurowski, B.G., Taylor, H.G., Yeates, K.O., Walz, N.C., Stancin, T., \& Wade, S.L. (2011). Caregiver ratings of long-term executive dysfunction and attention problems after early childhood traumatic brain injury: Family functioning is important. Archives of $P M \& R$, 3(9), 836-845. https://doi.org/10.1016/j.pmrj.2011.05.016

Li, L., \& Liu, J. (2013). The effect of pediatric traumatic brain injury on behavioral outcomes: Systematic review. Developmental Medicine \& Child Neurology, 55(1), 37-45. https://doi.org/10.1111/j.1469-8749.2012.04414.x

Limond, J., Dorris, L., \& McMillan, T. M. (2009). Quality of life in children with acquired brain injury: Parent perspectives 1-5 years after injury. Brain Injury, 23(7-8), 617-622. https://doi.org/10.1080/02699050902997870

Massachusetts Department of Elementary and Special Education (2018). Retrieved from http://www.doe.mass.edu/sped/links/brain.html

Minnesota Department of Corrections. (2015). TBI in Minnesota Correctional Facilities. Retrieved from https://mn.gov/doc/assets/TBI_White_Paper_MN_DOC-DHS_tcm1089272843.pdf

Moser, R. S., Schatz, P., \& Jordan, B. D. (2005). Prolonged effects of concussion in high school athletes. Neurosurgery, 57(2), 300-306. https://doi.org/10.1227/01.NEU.0000166663.98616.E4 
Myers R.K., Eagan-Brown B.L., Conway A.T., Nagele, D., Vaccaro M.J., Kendi S., \& Zonfrillo, M.R. (2018) Examining a statewide educational consulting program for pediatric brain injury. Clinical Pediatrics, 57(6), 645-655. https://doi.org/10.1177/0009922817732146

National Center for Injury Prevention and Control. (2003). Report to congress on mild traumatic brain injury in the United States: Steps to prevent a serious public health problem. Atlanta, GA: Centers for Disease Control and Prevention.

Ohio Brain Injury Program \& Brain Injury Advisory Committee. (2018). Biennial report on the incidence of traumatic brain injury in Ohio. Columbus, $\mathrm{OH}$ : Ohio State University, Wexner Medical Center.

Prasad, M. R., Swank, P. R., \& Ewing-Cobbs, L. (2017). Long-term school outcomes of children and adolescents with traumatic brain injury. Journal of Head Trauma Rehabilitation, 32(1), e24-e32. https://doi.org/10.1097/HTR.0000000000000218

Rivara, F. P., Koepsell, T. D., \& Wang, J. (2012). Incidence of disability among children 12 months after traumatic brain injury. American Journal of Public Health, 102(11), 20742079. https://doi.org/10.2105/AJPH.2012.300696

Rivara, F. P., Vavilala, M. S., \& Durbin, D. (2012). Persistence of disability 24 to 36 months after pediatric traumatic brain injury: A cohort study. Journal of Neurotrauma, 29(15), 2499-2504. https://doi.org/10.1089/neu.2012.2434

Ryan, N. P., Catroppa, C., Godfrey, C., Noble-Haeusslein, L. J., Shultz, S.R., O’Brein, T.J.

Semple, B.D. (2016). Social dysfunction after pediatric traumatic brain injury: A translational perspective. Neurosci Biobehav Rev, 64, 196-214. Retrieved from https://doi.org/10.1016/j.neubiorev.2016.02.020.

Schwab K.A., Ivins B., Cramer G., Johnson, W., Sluss-Tiller, M., Kiley, K., Warden, D. (2007). Screening for traumatic brain injury in troops returning from deployment in Afghanistan and Iraq: Initial investigation of the usefulness of a short screening tool for traumatic brain injury. Journal of Head Trauma Rehabilitation, 22(6), 377-389. https://doi.org/10.1097/01.HTR.0000300233.98242.87

Taylor, C.A., Bell, J.M., Breiding, M.J., \& Xu, L. (2017). Traumatic brain injury-related emergency department visits, hospitalizations, and deaths — United States, 2007 and 2013. MMWR Surveillance Summary, 66(SS-9), 1-16. Retrieved from http://dx.doi.org/10.15585/mmwr.ss6609a1

Todis, B., \& Glang, A. (2008). Redefining success: Results of a qualitative study of postsecondary transition outcomes for youth with traumatic brain injury. Journal of Head Trauma Rehabilitation, 23(4), 252-263. https://doi.org/10.1097/01.HTR.0000327257.84622.bc

Todis, B., Glang, A., \& Fabry, M. A. (1997). Family-school-child: A qualitative study of the school experiences of students with ABI. in Students with Acquired Brain Injury: The School's Response (pp. 33-72). Baltimore, MD: Paul H. Brookes. 
Todis, B., McCart, M., Glang, A. (2018). Hospital to school transition following traumatic brain injury: A qualitative longitudinal study. NeuroRehabilitation, 42(3), 269-276. https://doi.org/10.3233/NRE-172383

U.S. Census Bureau, American Fact Finder. (2013). Population estimates. Retrieved from http://factfinder.census.gov

U.S. Department of Education. (2013). IDEA Part B child count and educational environments. Retrieved from https://www2.ed.gov/programs/osepidea/618-data/state-level-datafiles/index.html.

Vaughn, S. (2014). Special education \& traumatic brain injury (TBI): A summary of state definitions and guidance for education students with TBI-related disabilities. Washington, DC: National Association of State Head Injury Administrators.

Yeates, K.O., Armstrong, K., \& Janusz, J. (2005). Long-term attention problems in children with traumatic brain injury. Journal of American Academy Children Adolescent Psychiatry, 44(6), 574-584. https://doi.org/10.1097/01.chi.0000159947.50523.64

Zaloshnja, E., Miller, T., Langlois, J. A., \& Selassie, A. W. (2008). Prevalence of long-term disability from traumatic brain injury in the civilian population of the United States, 2005. 
Physical Disabilities: Education and Related Services, 2019, 38(1), 26-44. doi: 10.14434/pders.v38i1.27477

(C) Division for Physical, Health and Multiple Disabilities

PDERS

ISSN: 2372-451X

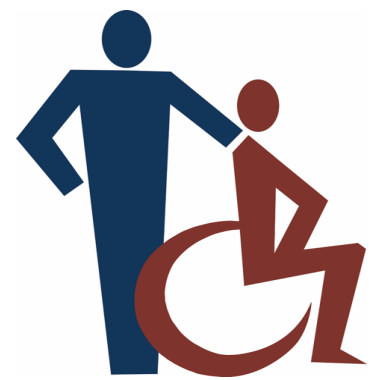

http://scholarworks.iu.edu/journals/index.php/pders/index

Article

STUDENTS WITH ACQUIRED BRAIN INJURY: A LEGAL UPDATE

Perry Zirkel

Lehigh University

\begin{abstract}
Representing a sequel to a similar case law snapshot in mid-2010, this article provides an updated overview of the judicial and administrative case law concerning students with traumatic and nontraumatic brain injury in the $\mathrm{P}-12$ school context. The scope is limited to cases under the Individuals with Disabilities Education Act and the pair of disability-based civil rights statutes, Section 504 and the Americans with Disabilities Act. The cases include not only hearing/review officer and court decisions but also state education agency and Office for Civil Rights complaint investigation reports available in the national legal database, LRP's SpecialEdConnection ${ }^{\circledR}$. The analysis focuses on the frequency and outcomes of these published rulings, with the discussion extending to the empirical limitations and professional implications of the findings.
\end{abstract}

Acquired brain injury (ABI) generically encompasses both traumatic and nontraumatic brain injury (e.g., Savage \& Wolcott, 1994). The express exclusion is for brain injuries that are "congenital or ... induced by birth trauma" (p. 4).

The pertinent professional literature continues to abound across fields, including special education, school psychology, social work, and pediatrics, although not necessarily within them (e.g., Smith \& Canto, 2015). The foci of these various articles include characteristics and incidence (e.g., Blankenship \& Canto, 2018), symptomology (e.g., Rees, 2016); instrumentation (e.g., Cohen et al., 2019; Lindsey, Hurley, Mozeiko, \& Coelho, 2019); teacher training (e.g., Davies, Fox, Glang, Ettel, \& Thomas, 2013; Ettel, Glang, Todis, \& Davies, 2016), treatment (e.g., Kelly, Dunford, Forsyth, \& Kavcic, 2019), and, especially, interventions (e.g., Canto \& Eftaxas, 2018; Chavez-Arana et al., 2018; Davies, 2016; Jantz, Davies, \& Bigler, 2014; Utley, Obiakor, \& Obi, 2019) of ABI.

The coverage of the legal dimension of $\mathrm{ABI}$ in the $\mathrm{K}-12$ context remains largely limited. 
For example, Glang et al. (2015) identified only a few state laws in their report of a 2012 survey of state directors of special education on supports and services for students with traumatic brain injury (TBI). Similarly, Cole and Cecka (2014) analyzed only a small sample of court decisions specific to employees with TBI, with only one case in the school context.

In the major exception, Zirkel (2011) outlined, as a framework, the pertinent legislative, regulatory, and agency policy interpretations under the Individuals with Disabilities Act (IDEA, 2017) and the related pair of civil rights laws-Section 504 of the Rehabilitation Act (2017) and the Americans with Disabilities Act (ADA, 2017). Based on an earlier explanation of the alternative decisional avenues (Zirkel \& McGuire, 2010), Zirkel (2011) identified the two administrative dispute resolution mechanisms - each state education agency's (SEA's) complaint investigation procedures under the IDEA and the corresponding Office for Civil Rights (OCR) complaint procedure under Section 504 and the ADA - and the two levels of adjudicative dispute resolution - the impartial hearing and the judicial appeals under these statutes. Within this framework, he next canvassed the adjudicative and administrative case law specific to students with ABI in the $\mathrm{K}-12$ context. More specifically, he found a total of 53 cases from 1990 to mid2010, with two thirds of the cases decided during the second half of the period. The distribution of the cases for the four forums was as follows: SEA complaint investigations - 2; OCR complaint investigations - 10; hearing and review officer decisions -22 ; and court decisions 19. Finally, he analyzed the outcomes of these cases in terms of the following broad issue categories: eligibility, including child find; free appropriate public education (FAPE), including placement and least restrictive environment; related services; discipline; compensatory education; reimbursement, including independent educational evaluations at public expense; adjudicative issues, such as statute of limitations; and legal bases other than the IDEA. The 53 cases yielded 79 issue category rulings, with the most frequent category being FAPE. The overall outcomes distribution of the issue category rulings was as follows: conclusively in favor of parents $-28 \%(\mathrm{n}=22)$; intermediate, such as rulings for further proceedings $-14 \%(\mathrm{n}=11)$; and conclusively in favor of districts $-58 \%(\mathrm{n}=46)$ (Zirkel, 2011).

\section{Scope and Method for Updated Case Law Analysis}

The purpose of this article is to provide a follow-up analysis of the corresponding adjudicative and administrative decisions. The specific period was from mid-2010 to mid-2019.

The method was basically the same as the previous analysis (Zirkel, 2011) with a few refinements. First, the exclusions consisted of not only cases of congenital brain injuries (e.g., Nicholas v. Norristown Area School District, 2017) and hearing officer decisions superseded by a subsequent court decision for the same case within the same time period (e.g., Warrior Run School District, 2014), but also (a) rulings beyond those under the IDEA and Section 504/ADA, such as the Fourteenth Amendment (e.g., A.M.C. v. School District of La Crosse, 2018; Mann v. Palmerton Area School District, 2017; Tristan v. Socorro Independent School District, 2012), or state civil rights laws (e.g., Trujillo v. Sacramento Unified School District, 2018), and (b) adjudicative subcategories that seemed too marginal, such as a homogeneous cluster of approximately a dozen stay-put rulings for the same New York City advocacy group (e.g., 
Navarro Carrilo v. New York City Department of Education, 2019; New York City Department of Education, 2019) and interlocutory rulings (e.g., Carr v. Department of Public Instruction, 2018).

The second refinement consisted of the following changes to the issue categories: (a) relabelling the "eligibility" category to "identification" so as to more clearly encompass the overlapping but separable subcategory of child find; (b) subsuming related services within the FAPE category due to negligible frequency; (c) conflating compensatory education and reimbursement into a remedies category for more overall consistency, (d) providing dual categorization of the $\S 504 / A D A-r e s t r i c t e d$ category, and (e) adding a miscellaneous category as a catchall for the relatively few other rulings.

The third refinement was to revise the outcome scale for the rulings in terms of conclusiveness. The result was three categories: $\mathrm{P}=$ conclusively in favor of the parent; Inc.=inconclusive; and $\mathrm{S}=$ conclusively in favor of the school district. An asterisk designated the conclusive outcomes that had a limited qualification, such as a voluntary resolution agreement for the OCR outcome or limited relief for a secondary issue in a court outcome.

\section{Results of the Updated Case Law Analysis}

As specifically identified in the Appendix, the total number of cases was 89 for the updated period from mid-2010 to mid-2019. The frequency distribution for each of the four forums was as follows: state complaint investigation procedures (CIP) decisions - 11; OCR decisions - 9; hearing/review officer $(\mathrm{H} / \mathrm{RO})$ decisions -40 ; court decisions -29 . Because some of the decisions had more than one issue category ruling and it is the more precise unit of analysis for outcomes, Table I presents the outcomes distribution for each of the four forums in terms of the 106 issue category rulings. The first column includes the average ratio (r) of issue category rulings per decision, and the other three columns provide the percentage and number (n) for each of the aforementioned outcomes categories.

Table 1. Rulings Distribution for the Four Decisional Forums

\begin{tabular}{|l|c|c|c|}
\hline & For Parent & Inconclusive & For District \\
\hline $\begin{array}{c}\text { CIP }(\mathrm{n}=11 \text { decisions }) \\
(\mathrm{r}=1.1)\end{array}$ & $58 \%(\mathrm{n}=7)$ & 0 & $42 \%(\mathrm{n}=5)$ \\
\hline $\begin{array}{c}\text { OCR }(\mathrm{n}=9 \text { decisions }) \\
(\mathrm{r}=1.3)\end{array}$ & $75 \%(\mathrm{n}=9)^{\mathrm{a}}$ & 0 & $25 \%(\mathrm{n}=3)$ \\
\hline $\begin{array}{c}\mathrm{H} / \mathrm{RO}(\mathrm{n}=40 \text { decisions }) \\
(\mathrm{r}=1.1)\end{array}$ & $41 \%(\mathrm{n}=18)$ & $2 \%(\mathrm{n}=1)$ & $57 \%(\mathrm{n}=25)^{\mathrm{b}}$ \\
\hline $\begin{array}{c}\text { Court }(\mathrm{n}=29 \text { decisions })^{\mathrm{c}} \\
(\mathrm{r}=1.3)\end{array}$ & $11 \%(\mathrm{n}=4)$ & $13 \%(\mathrm{n}=5)$ & $76 \%(\mathrm{n}=29)^{\mathrm{d}}$ \\
\hline $\begin{array}{c}\text { TOTAL } \\
(\mathrm{r}=1.1)\end{array}$ & $36 \%(\mathrm{n}=38)$ & $6 \%(\mathrm{n}=6)$ & $58 \%(\mathrm{n}=62)$ \\
\hline
\end{tabular}

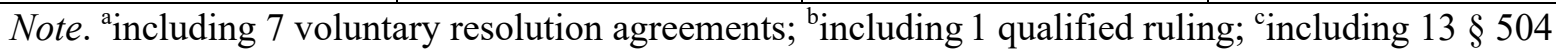




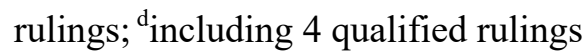

Review of Table 1 reveals that the issue category rulings within the two investigative forums favored parents, whereas those in the two succeeding adjudicative forums predominated in favor of districts. Primarily attributable to the higher ratio of rulings to decisions and the particularly pro-district skew in the 29 court cases, the total outcomes distribution of rulings favored districts on approximately a $60 \%-40 \%$ average upon discounting the limited number of inconclusive and qualified rulings.

A supplementary view of the Appendix reveals that the 'issues' categories for the two administrative forums were primarily FAPE and to a lesser extent identification. The H/RO and court cases yielded a wider variety of issue categories in addition to the predominance of FAPE, especially remedies and adjudicative issues. The respective statutory authorization limited the CIP and OCR rulings to the IDEA and Section 504/ADA, respectively. In contrast, in light of the more open-ended jurisdiction of the adjudicative forums, claims under Section 504/ADA arose in addition or alternative to those under IDEA at the court level, accounting for 13 of the 38 judicial rulings.

Table 2 shows the frequency and outcomes distribution for each of the issue categories.

Table 2. Rulings Distribution for the Various Issue Categories

\begin{tabular}{|l|c|c|c|}
\hline & For Parent & Inconclusive & For District \\
\hline $\begin{array}{c}\text { Adjudicative } \\
(\mathrm{n}=16)\end{array}$ & $6 \%(\mathrm{n}=1)$ & $25 \%(\mathrm{n}=4)$ & $69 \%(\mathrm{n}=11)^{\mathrm{c}}$ \\
\hline $\begin{array}{c}\text { Identification } \\
(\mathrm{n}=15)\end{array}$ & $47 \%(\mathrm{n}=7)^{\mathrm{a}}$ & $6 \%(\mathrm{n}=1)$ & $47 \%(\mathrm{n}=7)$ \\
\hline $\begin{array}{c}\text { FAPE } \\
(\mathrm{n}=55)\end{array}$ & $42 \%(\mathrm{n}=23)^{\mathrm{b}}$ & $2 \%(\mathrm{n}=1)$ & $56 \%(\mathrm{n}=31)^{\mathrm{d}}$ \\
\hline $\begin{array}{c}\text { Remedies } \\
(\mathrm{n}=11)\end{array}$ & $45 \%(\mathrm{n}=5)$ & $0 \%(\mathrm{n}=0)$ & $55 \%(\mathrm{n}=6)$ \\
\hline $\begin{array}{c}\text { Misc. incl. Discipline } \\
(\mathrm{n}=9)\end{array}$ & $22 \%(\mathrm{n}=2)$ & $0 \%(\mathrm{n}=0)$ & $78 \%(\mathrm{n}=7)$ \\
\hline
\end{tabular}

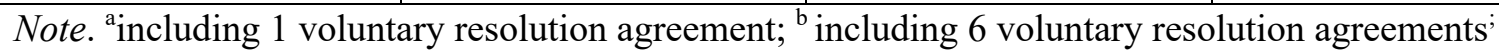
${ }^{c}$ including 1 qualified ruling; ${ }^{\text {including } 4}$ qualified rulings 
Table 2 shows that FAPE accounted for slightly more than half of the issue category rulings and that parents did not prevail in the majority of the rulings for any of these broad issue categories. The adjudicative category, which is largely attributable to the court forum, accounted for most of the inconclusive rulings, although the noted qualified rulings overlap with this intermediaterange outcome.

\section{Interpretation and Implications of the Findings}

In comparison to the predecessor analysis (Zirkel, 2011), the frequency of legal activity in the four decisional forums for students with ABI increased significantly, with a total of 89 cases for the most recent nine-year period compared to 54 cases for the previous 20 -year period. This growth is attributable at least in part to the upward trajectory legal activity more generally under the IDEA and Section 504/ADA, but the available data concerning the corresponding overall activity are not sufficiently current and comprehensive for a sufficiently precise comparison (e.g., CADRE, 2018; Karanxha \& Zirkel, 2014; Zirkel \& Skidmore, 2014).

Within this increased total, the distribution among the four decisional forums remained skewed in favor of the adjudicative arena, although the frequency of traffic in the investigative avenues shifted notably from the OCR to the SEA complaint procedures avenue. Nevertheless, the increased but still limited share of state CIP decisions for the current period, which amounted to $12 \%$ as compared to $4 \%$ of the cases in the previous period, remains less than expected in light of the much lower costs and more favorable outcomes for parents in not only the ABI cases but also more generally (e.g., CADRE, 2018; Zirkel, 2017). The relative under-use of the CIP forum is likely due to lack of parental awareness of the cost-benefits of this avenue and its de-emphasis by parent attorneys, which is likely attributable in part to self-interest and in part to normative orientation in favor of the adjudicative process.

The overall outcomes distribution was similar to that for the previous period (Zirkel, 2011), although the proportion of inconclusive outcomes was moderately lower. For the conclusive outcomes categories, the overall 60-40 balances in favor of districts not only continued from the previous period but also aligned with the general pro-district pattern in special education litigation (e.g., Karanxha \& Zirkel, 2014; Zirkel \& Skidmore, 2014). Although the more general analyses are largely limited to the adjudicative arena, the $\mathrm{H} / \mathrm{RO}$ and judicial forums predominate for the ABI rulings. Moreover, as Zirkel and Skidmore (2014, p. 540) explained, the units of analysis and the categories of outcomes are subject to imprecise and varying interpretations. Not to be ignored, the intermediate outcomes, including both the inconclusive and the qualified rulings may well be of practical significance to the parties in terms of leverage for not only settlements but also attorneys' fees. For example, in the New York case of South Orange Central School District (2019), the review officer ruled against the parents for all of their numerous FAPE claims except the limited one specific to counseling services. As a result, the review officer rejected the parents' request for prospective placement in a private school, various independent educational evaluations, compensatory education for several specified related services and 529 hours of 1:1 tutoring services; however, the review officer 
ordered a total of 22.5 hours of compensatory education for missed counseling sessions. This relatively limited qualified gloss on an outcome otherwise conclusively in favor of the district represented not only an additional outlay of services to the student but also the basis for a potentially costly attorneys' fees award to the parents. Another source of imprecision is the skewing effect of mixed rulings for which only one party appealed, which more often was the parent. For example, in A.C. v. Capistrano Unified School District (2018), the H/RO ruling for child find was in favor of the parents, but their appeal was to the limited remedy and the FAPE issue. The selective reporting of the final decision, which was in favor of the district, contributed to the skew in the distribution at both of these successive levels.

Within the overall outcomes distribution, despite the methodological refinements here and variations more generally, three findings remain primary and consistent. First, the predominance of FAPE rulings is consistent with the results of the previous analysis (Zirkel, 2011) and the aforementioned more general outcomes analyses in special education litigation. The converse low incidence and even more parent-favorable outcomes for remedies aligns with other analyses (Zirkel, 2013; Zirkel \& Skidmore, 2014) and is attributable to the screening and skewing effect of the prerequisite for compensatory education and tuition reimbursement of a denial of FAPE.

Second, the limited but notable frequency $(n=16)$ of adjudicative rulings, such as stayput, statute of limitations, and exhaustion of administrative remedies, are, as the Appendix shows, limited to the rulings by H/ROs $(5$ of $44=11 \%)$ and courts $(11$ of $38=29 \%)$. Moreover, the aforementioned exclusion of the homogeneous cluster of stay-put cases in New York, which would have considerably inflated these numbers, reflects the potential role of an advocacy organization with a particular interest. More generally, these highly technical but often significant issues reflect the increasing legalization of special education litigation, including the "judicialization" of the hearing and review officer systems (Connolly, Zirkel, \& Mayes, in press).

Third and similarly consistent with the previous analysis, the rubric of $\mathrm{ABI}$ includes not only legal inconsistency between TBI and nTBI but also and more importantly the wide variety of individual differences within these imprecise legal categories. Thus, for both identification and FAPE cases, the rulings are inevitably fact-specific, defying over-generalization. For example, in Hillsborough County School Board (2014), the hearing officer concluded: "As this case plainly demonstrates, TBI is not a one-size-fits-all classification" (pp. 30-31).

The limitations of this empirical analysis include not only the inevitable imprecision of the classification of issues and outcomes in light of the blurry, often overlapping boundaries within, and the individualized nature of, the IDEA and Section 504/ADA, but also the imperfect representation of the total population of these ABI cases within the legal publication process. Moreover, even if one obtained the complete population of $\mathrm{ABI}$ decisions for each of the four forums of the IDEA and Section 504/ADA, it would miss the skewing effect of the much larger number of ABI cases resolved via abandonment or settlement prior to the final decisional stage (e.g., Zirkel \& Holben, 2017). 


\section{Conclusion}

Confirming the findings of the predecessor analysis, this updated snapshot of the ABI case law activity in the decisional dispute resolution mechanism under the IDEA and Section 504/ADA show that the adjudicative arena predominates in terms of parental choice but the investigative forums are more favorable in terms of parental outcomes. Similarly reflecting the more general trend of the case law under these federal disability laws, FAPE is the major issue, and adjudicative issues are a limited but not negligible transactional trade-off for the primary reliance on the successive $\mathrm{H} / \mathrm{RO}$ and judicial avenues. A more intensive and qualitative analysis of the case law is a recommended area for follow-up research. The extension to other legal bases, as the partly overlapping and analogous analysis of student concussion cases (Zirkel, 2016) illustrates, is an additional line of further research. Such investigation will likely find that the nuances of ABI, as reflected in the evidence-based professional literature, are largely lost in the decision-making process of these legal forums due in part to their (a) emphasis on procedural matters, (b) lack of specialized expertise, and (c) congested level of activity. Another major contributing factor, as the final column in the Appendix reveals, is that often the ruling does not depend on the ABI status of the child due to either the purely procedural or adjudicative nature of the issue or the concomitance of additional disability diagnoses.

In sum, the conclusion repeats with reinforcement the ending of its predecessor (Zirkel, 2011): "This relatively comprehensive and current canvassing of the various sources of law specific to students with $[\mathrm{ABI}]$ in pre-K through grade 12 serves as a primer of special education law for parents, advocates, and school personnel with a special interest in these children" (pp. 38-39). Thus, it adds to the focused foundation for obtaining a more complete understanding of the issues and forums for decisional dispute resolution under the IDEA and Section 504/ADA for students with ABI specifically and students with disabilities more generally. 
References

A.M.C. v. Sch. Dist. of La Crosse, 73 IDELR $q 4$ (W.D. Wis. 2018).

Americans with Disabilities Act, 42 U.S.C. $\S \S 12102$ et. seq. (2017).

Blankenship, A. P., \& Canto, A. I. (2018). Traumatic brain injuries and special education services in the schools. Exceptionality, 26(4), 218-229.

doi:10.1080/09362835.2016.1238379

CADRE (2018). National dispute resolution data summary for U.S. and outlying areas 2004-05 to 2016-17. Retrieved from https://www.cadreworks.org/sites/default/files/resources/201617\%20DR\%20Data\%20Summary\%20-\%20National.pdf

Canto, A. I., \& Eftaxas, D. M. (2018). Interventions for learners with traumatic brain injuries. Advances in Special Education, 33, 169-182. doi:10.1108/S0270-40132010000031010

Carr v. Dep't of Pub. Instruction, 71 IDELR \ 166 (W.D. Wis. 2018).

Chavez-Arana, C., Catroppa, C., Carranza-Eacarcega, E., Godfrey, C., Yanez-Tellez, D. G., Prieto-Corona, B., ... \& Anderson, V. (2018). A systematic review of interventions for hot and cold executive functions in children and adolescents with acquired brain injury. Journal of Pediatric Psychology, 43, 928-942. doi: 10.1093/jpepsy/jsy013

Cohen, M. L., Tulsky, D. S., Boulton, A. J., Kisala, P. A., Bertisch, H., Yeates, K. O., ... \& Rivara, P. (2019). Reliability and construct validity of the TBI-QOL Communication Short Form as a parent-proxy report instrument for children with traumatic brain injury. Journal of Speech, Language, and Hearing Research, 62, 84-92. doi:10.23641/asha.7616534

Cole, P. L., \& Cecka, D. M. (2014). Traumatic brain injury and the Americans with Disabilities Act: Implications for the social work profession. Social Work, 59, 261-269. doi: 10.1093/sw/swu015

Connolly, J. F., Zirkel, P. A., \& Mayes, T. A. (in press). State due process systems under the IDEA: An update. Journal of Disability Policy Studies. https://doi.org/10.1177/1044207319836660

Davies, S. C. (2016). School-based traumatic brain injury and concussion management program. Psychology in the Schools, 53, 567-582. doi:10.1002/pits.21927

Davies, S. C., Fox, E., Glang, A., Ettel, D., \& Thomas, C. (2013). Traumatic brain injury and teacher training: A gap in educator preparation. Physical Disabilities: Education and Related Services, 32(1), 55-65. Retrieved from http://community.cec.sped.org/dphmd/journal

Ettel, D., Glang, A. E., Todis, B., \& Davies, S. C. (2016). Traumatic brain injury: Persistent misconceptions and knowledge gaps among educators. Exceptionality Education International, 26, 1-18. Retrieved from http://ir.lib.uwo.ca/eei/vol26/iss1/1 
Glang, A., Ettel, D., Todis, B., Gordon, W. A., Oswald, J. M., Vaughn, S. L., ... \& Brown, M. (2015). Services and supports for students with traumatic brain injury: Survey of state education agencies. Exceptionality, 23, 211-224. doi: 10.1080/09362835.2014.986612

Individuals with Disabilities Education Act, 20 U.S.C. $\S \S 1401$ et seq. (2017).

Karanxha, Z., \& Zirkel, P. A. (2014). Trends in special education case law: Frequency and outcomes of published court decisions 1998-2012. Journal of Special Education Leadership, 27(2), 55-65. Retrieved from http://www.casecec.org/resources/jsel.asp

Jantz, P. B., Davies, S. C., \& Bigler, E. D. (2014). Working with traumatic brain injury in schools: Transition, assessment, and intervention. New York, NY: Routledge. Retrieved from https://ecommons.udayton.edu/edc_fac_pub/52/

Kelly, G., Dunford, C., Forsyth, R., \& Kavcic, A. (2019). Using child- and family-centered goalsetting as an outcome measure of residential rehabilitation for children and youth with acquired brain injuries. Child Care Health and Development, 45, 286-291. doi $0.1111 /$ cch. 12636

Lindsey, A., Hurley, E., Mozeiko, J., \& Coelho, C. (2019). Follow up on the Story Goodness Index for characterizing discourse deficits following traumatic brain injury. American Journal of Speech-Language Pathology, 28, 300-340. doi: 10.1044/2018_AJSLP-170151

Mann v. Palmerton Area Sch. Dist., 872 F.3d 165 (3d Cir. 2017).

Navarro Carrilo v. N.Y.C. Dep’t of Educ., 384 F. Supp. 3d 441 (S.D.N.Y. 2019).

N.Y.C. Dep't of Educ., 119 LRP 4663 and 119 LRP 4657 (N.Y. SEA 2019).

Nicholas v. Norristown Area Sch. Dist., 69 IDELR 1116 (E.D. Pa. 2017).

Rees, S. (2016). Where have they all gone?: Classroom attention patterns after acquired brain injury. Journal of Research in Special Education Needs, 16(3), 147-155. doi:

10.1111/1471-3802.12104

Savage, R. C., \& Wolcott, G. F. (1994). Educational dimensions of acquired brain injuries. Austin, TX: Pro-Ed.

Section 504 of the Rehabilitation Act. 29 U.S.C. $\S \S 705(20)$ and 794 (2017).

Smith, S. M., \& Canto, A. I. (2015). Trends in traumatic brain injury research in school psychology journals 1985-2014. School Psychology Forum, 9(3), 165-183. Retrieved from http://www.nasponline.org/publications/

S. Orange Cent. Sch. Dist., 119 LRP 15955 (N.Y. SEA 2019).

Tristan v. Socorro Indep. Sch. Dist., 902 F. Supp. 2d 870 (W.D. Tex. 2012).

Trujillo v. Sacramento Unified Sch. Dist., 71 IDELR 9212 (C.D. Cal. 2018).

Utley, C. A., Obiakor, F. E., \& Obi, S. (2019). Teaching young children with traumatic brain injury in inclusive classroom settings. Advances in Special Education, 34, 139-155. doi: http://dx.doi.org/10.1108/s0270-401320190000034009

Warrior Run Sch. Dist., 64 IDELR $\ 260$ (Pa. SEA 2014).

Zirkel, P. A. (2011). Students with acquired brain injury: A legal analysis. Physical Disabilities: Education and Related Services, 30(2), 23-47. doi: 10.11008/SO270- 
401320190000034009

Zirkel, P. A. (2013). Adjudicative remedies for denials of FAPE under the IDEA. Journal of the National Association of Administrative Law Judiciary, 33, 214-241. Retrieved from https://law.pepperdine.edu/naalj/

Zirkel, P. A. (2016). Court decisions specific to public school responses to student concussions. Physical disabilities: Education and Related Services, 35(1), 1-16. doi: 10.14434/pders.v35i1.20696

Zirkel, P. A. (2017). The two decisional dispute resolution processes under the Individuals with Disabilities Education Act: An empirical comparison. Connecticut Public Interest Law Journal,16, 169-207. Retrieved from https://cpilj.law.uconn.edu/\#

Zirkel, P. A., \& Holben, D. M. (2017). Spelunking the litigation iceberg: Exploring the ultimate outcomes of inconclusive rulings. Journal of Law \& Education, 46, 195-217. Retrieved from https://sc.edu/study/colleges_schools/law/student_life/journals/jled/index.php

Zirkel, P. A., \& McGuire, B. L. (2010). A roadmap to legal dispute resolution for students with disabilities. Journal of Special Education Leadership, 23, 100-112. Retrieved from http://www.casecec.org/resources/jsel.asp

Zirkel, P. A., \& Skidmore, C. A. (2014). National trends in the frequency and outcomes of hearing and review officer decisions under the IDEA: An empirical analysis. Ohio State Journal on Dispute Resolution, 29, 525-576. Retrieved from https://moritzlaw.osu.edu/osjdr/

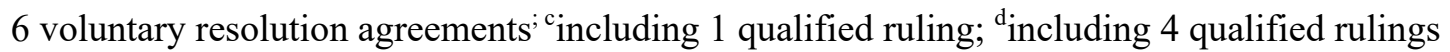


Appendix: Compilation of Decisions and Issue Category Rulings for Each of the Four Alternative Forums

\begin{tabular}{|c|c|c|c|c|}
\hline Case Name & Citation & Issue Category & $\begin{array}{l}\text { Rul- } \\
\text { ing }\end{array}$ & Comment \\
\hline \multicolumn{5}{|c|}{ Complaint Investigation Procedures (CIP) Decisions $(n=11)$} \\
\hline $\begin{array}{l}\text { Seminole Cty. Sch. } \\
\text { Dist. }\end{array}$ & $\begin{array}{l}\text { 114 LRP } 9296 \\
\text { (Fla. SEA 2010) }\end{array}$ & FAPE & $\mathrm{P}$ & 3,4-procedural \\
\hline $\begin{array}{l}\text { St. Cloud Indep. Sch. } \\
\text { Dist. \#742 }\end{array}$ & $\begin{array}{l}110 \text { LRP } 40192 \\
\text { (Minn. SEA 2010) }\end{array}$ & FAPE & $\mathrm{P}$ & $\begin{array}{l}\text { 3,4-failure to implement and procedural (but only } \\
\text { partial) }\end{array}$ \\
\hline $\begin{array}{l}\text { Rapid City Area Sch. } \\
\text { Dist. }\end{array}$ & $\begin{array}{l}112 \text { LRP } 24614 \\
\text { (S.D. SEA 2010) }\end{array}$ & Identification & $\mathrm{S}$ & 3,4-including child find \\
\hline $\begin{array}{l}\text { Anne Arundel Cty. Pub. } \\
\text { Sch. }\end{array}$ & $\begin{array}{l}110 \text { LRP } 72199 \\
(\mathrm{Md} . \mathrm{SEA} 2010)\end{array}$ & FAPE & $\mathrm{P}$ & 3,4-AT, ESY \\
\hline $\begin{array}{l}\text { Strongsville City Sch. } \\
\text { Dist. }\end{array}$ & $\begin{array}{l}110 \text { LRP } 74236 \\
\text { (Ohio SEA 2010) }\end{array}$ & FAPE & $\mathrm{S}$ & 3,4-various procedural FAPE issues \\
\hline Brandywine Sch. Dist. & $\begin{array}{l}58 \text { IDELR } \uparrow 119 \\
\text { (Del. SEA 2011) }\end{array}$ & FAPE & $\mathrm{P}$ & $\begin{array}{l}\text { 3,4-inter-district transfer of student w. IEP and } \\
\text { absenteeism - marginal (Misc.) }\end{array}$ \\
\hline $\begin{array}{l}\text { In re Student with a } \\
\text { Disability }\end{array}$ & $\begin{array}{l}113 \text { LRP } 8908 \\
\text { (S.D. SEA 2012) }\end{array}$ & Remedies & $\mathrm{P}$ & $\begin{array}{l}\text { 3,4-IEE reimbursement (failure to evaluate all } \\
\text { suspected disabilities, including TBI due to } \\
\text { concussions) }\end{array}$ \\
\hline \multirow[t]{2}{*}{$\begin{array}{l}\text { E1 Paso Cty. Sch. Dist. } \\
3\end{array}$} & \multirow[t]{2}{*}{$\begin{array}{l}60 \text { IDELR } \uparrow 117 \\
\text { (Colo. SEA 2012) }\end{array}$} & Identification & $\mathrm{P}$ & $\begin{array}{l}\text { 3,4-delayed evaluation of child subsequently elig. as } \\
\text { TBI }\end{array}$ \\
\hline & & FAPE & $\mathrm{S}$ & 3,4-not predetermination or FTI (re bullying) \\
\hline Lakeview Sch. Dist. & $\begin{array}{l}64 \text { IDELR } \uparrow 89 \\
\text { (Mich. SEA 2013) }\end{array}$ & Identification & $\mathrm{P}$ & $\begin{array}{l}\text { E,4-child find violation-district disregarded parent's } \\
\text { request for an initial evaluation for TBI }\end{array}$ \\
\hline Montgomery Cty. Pub. & 115 LRP 24190 & FAPE & $\mathrm{S}$ & 3,4-IHP for post-concussive syndrome coordinated \\
\hline
\end{tabular}




\begin{tabular}{|c|c|c|c|c|}
\hline Sch. & (Md. SEA 2015) & & & $\begin{array}{l}\text { with IEP for OHI (ADD) adequately addressed TBI } \\
\text { needs }\end{array}$ \\
\hline $\begin{array}{l}\text { Jefferson Cty. Sch. Dist. } \\
\text { RE-1 }\end{array}$ & $\begin{array}{l}118 \text { LRP } 28108 \\
\text { (Colo. SEA 2018) }\end{array}$ & Identification & $\mathrm{S}$ & $3,4-504$ plan sufficed here \\
\hline \multicolumn{5}{|c|}{ Office of Civil Rights (OCR) Decisions (n=9) } \\
\hline $\begin{array}{l}\text { Fairfax Cty. (VA) Pub. } \\
\text { Sch. }\end{array}$ & $\begin{array}{l}112 \text { LRP } 15741 \\
(\text { OCR 2011) }\end{array}$ & $\begin{array}{l}\S 504 / \mathrm{ADA} \\
(\mathrm{FAPE})\end{array}$ & $\mathrm{P}^{*}$ & 3,4-district voluntarily agreed to various remedies \\
\hline $\begin{array}{l}\text { Cabarrus Cty. (NC) } \\
\text { Sch. }\end{array}$ & $\begin{array}{l}59 \text { IDELR } \uparrow 113 \\
(\text { OCR 2012) }\end{array}$ & $\S 504 /$ ADA (Elig.) & $\mathrm{P}^{*}$ & $\begin{array}{l}\text { 3,4-voluntarily agreed to evaluate child with TBI for } \\
\text { possible } 504 \text { plan and compensatory education }\end{array}$ \\
\hline $\begin{array}{l}\text { Miami-Dade Cty. (FL) } \\
\text { Pub. Sch. }\end{array}$ & $\begin{array}{l}60 \text { IDELR } 1234 \\
(\text { OCR 2012) }\end{array}$ & $\begin{array}{l}\S 504 / \mathrm{ADA} \\
(\mathrm{FAPE})^{\mathrm{DC}}\end{array}$ & $\mathrm{P}^{*}$ & $\begin{array}{l}\text { 3,4-partial child find-district voluntarily agreed to } \\
\text { evaluate child with TBI for speech therapy services }\end{array}$ \\
\hline $\begin{array}{l}\text { Blue Eye (MO) R-V } \\
\text { Sch. Dist. }\end{array}$ & $\begin{array}{l}113 \text { LRP 52486 } \\
\text { (OCR 2013) }\end{array}$ & $\begin{array}{l}\S 504 / \mathrm{ADA} \\
(\mathrm{FAPE})^{\mathrm{DC}}\end{array}$ & $\mathrm{P}^{*}$ & $\begin{array}{l}\text { 3,4-district voluntarily agreed to resolve summer } \\
\text { school exclusion w. various remedies - marginal } \\
\text { (limited facts) }\end{array}$ \\
\hline \multirow[t]{2}{*}{$\begin{array}{l}\text { Tucson (AZ) Unified } \\
\text { Sch. Dist. }\end{array}$} & \multirow[t]{2}{*}{$\begin{array}{l}114 \text { LRP } \\
(\text { OCR 2014) }\end{array}$} & $\begin{array}{l}\S 504 / \mathrm{ADA} \\
(\mathrm{FAPE})\end{array}$ & $\mathrm{S}$ & 3,4-implementation of 504 plan \\
\hline & & $\begin{array}{l}\S 504 / \mathrm{ADA} \\
\text { (Misc.) }\end{array}$ & $\mathrm{S}$ & 3,4-retaliation and intimidation \\
\hline \multirow[t]{3}{*}{$\begin{array}{l}\text { Dixon Cty. (TN) Sch. } \\
\text { Dist. }\end{array}$} & \multirow[t]{3}{*}{$\begin{array}{l}115 \text { LRP } 37687 \\
\text { (OCR 2015) }\end{array}$} & $\S 504 /$ ADA (Elig.) & $\mathrm{P}$ & $\begin{array}{l}\text { 3,4-failure to evaluate 504-only student for IDEA } \\
\text { elig. }\end{array}$ \\
\hline & & $\begin{array}{l}\S 504 / \mathrm{ADA} \\
\text { (Discip.) }\end{array}$ & $\mathrm{P}$ & $\begin{array}{l}\text { 3,4-Sat. school punishment for disability-related } \\
\text { behavior }\end{array}$ \\
\hline & & $\begin{array}{l}\S 504 / \mathrm{ADA} \\
\text { (Misc.) }\end{array}$ & $\mathrm{S}$ & $\begin{array}{l}\text { 3,4-reward system for non-bathroom use - } \\
\text { unfounded }\end{array}$ \\
\hline Utica (MI) Cmty. Sch. & $\begin{array}{l}116 \text { LRP } 12081 \\
(\text { OCR 2015) }\end{array}$ & $\begin{array}{l}\S 504 / \mathrm{ADA} \\
(\mathrm{FAPE})^{\mathrm{DC}}\end{array}$ & $\mathrm{P}^{*}$ & $\begin{array}{l}\text { 3,4-district voluntarily agreed to re-do IEP, incl. } \\
\text { reevaluation and parent participation }\end{array}$ \\
\hline $\begin{array}{l}\text { Harmony (TX) Pub. } \\
\text { Sch. }\end{array}$ & $\begin{array}{l}116 \text { LRP } 34809 \\
\text { (OCR 2016) }\end{array}$ & $\begin{array}{l}\S 504 / \mathrm{ADA} \\
(\mathrm{FAPE})^{\mathrm{DC}}\end{array}$ & $\mathrm{P}^{*}$ & $\begin{array}{l}\text { 3,4-district voluntarily agreed to implement disputed } \\
\text { accommodations/services - marginal (limited facts) }\end{array}$ \\
\hline
\end{tabular}




\begin{tabular}{|c|c|c|c|c|}
\hline $\begin{array}{l}\text { Traverse City (MI) } \\
\text { Area Pub. Sch. }\end{array}$ & $\begin{array}{l}117 \text { LRP } 7907 \\
\text { (OCR 2016) }\end{array}$ & $\begin{array}{l}\S 504 / \mathrm{ADA} \\
(\mathrm{FAPE})^{\mathrm{DC}}\end{array}$ & $\mathrm{P}^{*}$ & $\begin{array}{l}\text { 3,4-district voluntarily agreed to review and revise } \\
\text { IEP for use of adaptive stroller (but other claims } \\
\text { seemingly S) }\end{array}$ \\
\hline \multicolumn{5}{|c|}{ Hearing and Review Officer (H/RO) Decisions $(n=40)$} \\
\hline \multirow{3}{*}{$\begin{array}{l}\text { Garden Grove Unified } \\
\text { Sch. Dist. }\end{array}$} & \multirow{3}{*}{$\begin{array}{l}\text { 111 LRP } 63908 \\
\text { (Cal. SEA 2010) }\end{array}$} & Adjudicative & $\mathrm{S}$ & 3,4-stay-put \\
\hline & & FAPE & $\mathrm{P}$ & $\begin{array}{l}\text { 3,4-failure to implement full IEP } \rightarrow \text { compensatory } \\
\text { ed. plus transp. reimbursement }\end{array}$ \\
\hline & & FAPE & $\mathrm{S}$ & 3,4-evaluation and related services \\
\hline $\begin{array}{l}\text { District of Columbia } \\
\text { Pub. Sch. }\end{array}$ & $\begin{array}{l}\text { 111 LRP } 18455 \\
\text { (D.C. SEA 2010) }\end{array}$ & FAPE & $\mathrm{P}$ & $\begin{array}{l}\text { 3,4-including transition services } \rightarrow \text { prospective } \\
\text { placement plus }\end{array}$ \\
\hline $\begin{array}{l}\text { District of Columbia } \\
\text { Pub. Sch. }\end{array}$ & $\begin{array}{l}\text { 111 LRP } 1703 \\
\text { (D.C. SEA 2010) }\end{array}$ & Identification & $\mathrm{P}$ & $\begin{array}{l}\text { 3,4-elig. with FAPE overlap } \rightarrow \text { correct IEP and } \\
\text { compensatory ed. }\end{array}$ \\
\hline $\begin{array}{l}\text { Chi. Pub. Sch. Dist. } \\
\# 299\end{array}$ & $\begin{array}{l}\text { 111 LRP } 50962 \\
\text { (Ill. SEA 2010) }\end{array}$ & FAPE & $\mathrm{P}$ & 3,4-procedural FAPE $\rightarrow$ compensatory ed. \\
\hline $\begin{array}{l}\text { District of Columbia } \\
\text { Pub. Sch. }\end{array}$ & $\begin{array}{l}111 \text { LRP } 26545 \\
\text { (D.C. SEA 2010) }\end{array}$ & Remedies & $\mathrm{P}$ & 3,4-IEE at public expense \\
\hline $\begin{array}{l}\text { District of Columbia } \\
\text { Pub. Sch. }\end{array}$ & $\begin{array}{l}111 \text { LRP } 20830 \\
\text { (D.C. SEA 2010) }\end{array}$ & Remedies & $\mathrm{P}$ & 3,4-IEE at public expense \\
\hline $\begin{array}{l}\text { Newport-Mesa Unified } \\
\text { Sch. Dist. }\end{array}$ & $\begin{array}{l}\text { 111 LRP } 73203 \\
\text { (Cal. SEA 2010) }\end{array}$ & FAPE & $\mathrm{S}$ & 3,4-regular diploma \\
\hline Fanett-Metal Sch. Dist. & $\begin{array}{l}111 \text { LRP } 6384 \\
(\text { Pa. SEA 2010) }\end{array}$ & FAPE & $\mathrm{P}$ & $\begin{array}{l}\text { 3,4-insufficient evaluation and IEP } \rightarrow \text { compensatory } \\
\text { ed. }\end{array}$ \\
\hline Reg'l Sch. Unit No. 16 & $\begin{array}{l}111 \text { LRP } 39327 \\
\text { (Me. SEA 2011) }\end{array}$ & FAPE & $\mathrm{S}$ & 3,4-substantive; marginal due to multiple disabilities \\
\hline $\begin{array}{l}\text { Los Angeles Unified } \\
\text { Sch. Dist. }\end{array}$ & $\begin{array}{l}\text { 111 LRP } 58052 \\
(\text { Cal. SEA 2011) }\end{array}$ & FAPE & $\mathrm{P}$ & $\begin{array}{l}\text { 3,4-parental participation and failure to implement } \\
\rightarrow \text { compensatory ed. }\end{array}$ \\
\hline $\begin{array}{l}\text { Des Moines Indep. } \\
\text { Cmty. Sch. Dist. }\end{array}$ & $\begin{array}{l}114 \text { LRP } 28802 \\
\text { (Iowa SEA 2011) }\end{array}$ & FAPE & $\mathrm{S}$ & 3,4-substantive and procedural \\
\hline
\end{tabular}




\begin{tabular}{|c|c|c|c|c|}
\hline District of Columbia & $\begin{array}{l}113 \text { LRP } 18730 \\
\text { (D.C. SEA 2012) }\end{array}$ & FAPE & $\mathrm{P}$ & $\begin{array}{l}\text { 3,4-prospective placement; marginal case due to } \\
\text { only one of many disabilities }\end{array}$ \\
\hline Lakeshore Sch. Dist. & $\begin{array}{l}112 \text { LRP } 14671 \\
\text { (Wis. SEA 2012) }\end{array}$ & FAPE & $\mathrm{S}$ & \\
\hline District of Columbia & $\begin{array}{l}112 \text { LRP } 30738 \\
\text { (D.C. SEA 2012) }\end{array}$ & Remedies & $\mathrm{S}$ & 3,4-unproven need for compensatory ed. \\
\hline \multirow{2}{*}{$\begin{array}{l}\text { Shenandoah Valley } \\
\text { Sch. Dist. }\end{array}$} & \multirow{2}{*}{$\begin{array}{l}112 \text { LRP } 18993 \\
(\text { Pa. SEA 2012) }\end{array}$} & Adjudicative & $\mathrm{S}$ & 3,4-statute of limitations for prior period \\
\hline & & FAPE & $\mathrm{P}$ & 3,4-residence/enrollment issue $\rightarrow$ compensatory ed. \\
\hline $\begin{array}{l}\text { Prince George's Cty. } \\
\text { Sch. Bd. }\end{array}$ & $\begin{array}{l}112 \text { LRP } 49351 \\
(\mathrm{Md} . \mathrm{SEA} 2012)\end{array}$ & FAPE & $\mathrm{S}$ & 3,4-including evaluation \\
\hline \multirow{2}{*}{$\begin{array}{l}\text { Saddleback Valley } \\
\text { Unified Sch. Dist. }\end{array}$} & \multirow{2}{*}{$\begin{array}{l}\text { 112 LRP } 26103 \\
\text { (Cal. SEA 2012) }\end{array}$} & FAPE & $\mathrm{S}$ & 3,4-ESY - summers on each side of school year \\
\hline & & FAPE & $\mathrm{P}$ & $\begin{array}{l}\text { 3,4-LRE - school year } \rightarrow \text { tuition/transp. } \\
\text { reimbursement }\end{array}$ \\
\hline $\begin{array}{l}\text { N. St. Francois Cty. R-1 } \\
\text { Sch. Dist. }\end{array}$ & $\begin{array}{l}59 \text { IDELR \ } 179 \\
(\text { Mo. SEA 2012) }\end{array}$ & FAPE & $\mathrm{S}$ & $\begin{array}{l}\text { 3,4-LRE (move from gen. ed. to sp. ed. science } \\
\text { class) }\end{array}$ \\
\hline $\begin{array}{l}\text { Hillsborough Cty. Sch. } \\
\text { Bd. }\end{array}$ & $\begin{array}{l}60 \text { IDELR ๆ } 145 \\
\text { (Fla. SEA 2012) }\end{array}$ & FAPE & $\mathrm{S}$ & $\begin{array}{l}\text { 3,4-denied reimbursement due to appropriate IEP } \\
\text { (+untimely notice) }\end{array}$ \\
\hline $\begin{array}{l}\text { Dist. of Columbia Pub. } \\
\text { Sch. }\end{array}$ & $\begin{array}{l}\text { 114 LRP } 3890 \\
\text { D.C. SEA 2013) }\end{array}$ & Identification & Inc. & $\begin{array}{l}\text { 3,4-violation of child find w. reluctance but } \\
\text { dismissed compensatory ed. w/o prejudice pending } \\
\text { elig. evaluation }\end{array}$ \\
\hline $\begin{array}{l}\text { Palm Beach Cty. Sch. } \\
\text { Bd. }\end{array}$ & $\begin{array}{l}62 \text { IDELR } ₫ 307 \\
\text { (Fla. SEA 2013) }\end{array}$ & FAPE & $\mathrm{S}$ & $\begin{array}{l}\text { 3,4-low Rowley threshold and } \mathrm{B} / \mathrm{P} \text { on parents despite } \\
\text { reduced services after TBI to student with SLD }\end{array}$ \\
\hline Council Rock Sch. Dist. & $\begin{array}{l}\text { 114 LRP } 25058 \\
(\mathrm{~Pa} . \text { SEA 2014) }\end{array}$ & FAPE & $\mathrm{S}$ & $\begin{array}{l}\text { 3,4-provided appropriate school accommodations to } \\
\text { student with ED who experienced concussion }\end{array}$ \\
\hline Propel Charter Sch. & $\begin{array}{l}\text { 114 LRP } 41328 \\
\text { (Pa. SEA 2014) }\end{array}$ & FAPE & $\mathrm{S}$ & $\begin{array}{l}\text { 3,4-provided appropriate school accommodations to } \\
\text { student with SLD who experienced concussion }\end{array}$ \\
\hline E. Whittier Sch. Dist. & $\begin{array}{l}115 \text { LRP } 40940 \\
\text { (Cal. SEA 2015) }\end{array}$ & Remedies & $\mathrm{S}$ & $\begin{array}{l}\text { 3,4-IEE reimbursement - district's evaluation was } \\
\text { appropriate incl. failure to assess TBI because }\end{array}$ \\
\hline
\end{tabular}




\begin{tabular}{|c|c|c|c|c|}
\hline & & & & internal (chemotherapy) - marginal \\
\hline $\begin{array}{l}\text { Jefferson Cty. Sch. Dist. } \\
\text { R-1 }\end{array}$ & $\begin{array}{l}67 \text { IDELR } \ 250 \\
\text { (Colo. SEA 2015) }\end{array}$ & Misc. & $\mathrm{S}$ & $\begin{array}{l}\text { 3,4-consent for evaluation (overriding parent's many } \\
\text { conditions) - reasonable }\end{array}$ \\
\hline Mars Area Sch. Dist. & $\begin{array}{l}115 \text { LRP } 56455 \\
(\text { Pa. SEA 2015) }\end{array}$ & $\begin{array}{l}\S 504 / \text { ADA (Child } \\
\text { Find/FAPE) }\end{array}$ & $\mathrm{P}$ & $\begin{array}{l}\text { 3,4-failure for timely } 504 \text { evaluation and } 504 \text { plan } \rightarrow \\
\text { compensatory education }\end{array}$ \\
\hline Solon City Sch. Dist. & $\begin{array}{l}116 \text { LRP } 32555 \\
\text { (Ohio SEA 2016) }\end{array}$ & Remedies & $\mathrm{S}$ & $\begin{array}{l}\text { 3,4-district's evaluation was appropriate - thus, } \\
\text { denied IEE at public expense }\end{array}$ \\
\hline $\begin{array}{l}\text { District of Columbia } \\
\text { Pub. Sch. }\end{array}$ & $\begin{array}{l}118 \text { LRP } 11577 \\
\text { (D.C. SEA 2018) }\end{array}$ & FAPE & $\mathrm{P}$ & 3,4-child find $\rightarrow$ tuition reimbursement \\
\hline Mars Area Sch. Dist. & $\begin{array}{l}115 \text { LRP } 56455 \\
(\mathrm{~Pa} . \mathrm{SEA} 2015)\end{array}$ & $\begin{array}{l}\S 504 / \text { ADA (Child } \\
\text { Find/FAPE) }\end{array}$ & $\mathrm{P}$ & $\begin{array}{l}\text { 3,4-failure for timely } 504 \text { evaluation and } 504 \text { plan } \rightarrow \\
\text { compensatory education }\end{array}$ \\
\hline Eugene Sch. Dist. 4J & $\begin{array}{l}118 \text { LRP } 15830 \\
\text { (Or. SEA 2018) }\end{array}$ & Identification & $\mathrm{P}$ & $\begin{array}{l}\text { 3,4-concussion } \rightarrow \text { TBI elig. - compensatory ed. } \\
\text { (overlap w. FAPE) }\end{array}$ \\
\hline $\begin{array}{l}\text { District of Columbia } \\
\text { Pub. Sch. }\end{array}$ & $\begin{array}{l}118 \text { LRP } 23090 \\
\text { (D.C. SEA 2018) }\end{array}$ & FAPE & $P$ & $\begin{array}{l}\text { 3,4-substantive FAPE - though less relief than } \\
\text { parent sought }\end{array}$ \\
\hline Vilonia Sch. Dist. & $\begin{array}{l}72 \text { IDELR } \ 136 \\
\text { (Ark. SEA 2018) }\end{array}$ & Discipline & $\mathrm{P}$ & $\begin{array}{l}\text { 3,4-not requisite dangerousness for } 45 \text {-day interim } \\
\text { alternate educational setting }\end{array}$ \\
\hline $\begin{array}{l}\text { Dep't of Pub. } \\
\text { Instruction }\end{array}$ & $\begin{array}{l}118 \text { LRP } 40692 \\
\text { (Wis. SEA 2018) }\end{array}$ & Adjudicative & $\mathrm{S}$ & 3,4-statute of limitations \\
\hline Pittsburgh Sch. Dist. & $\begin{array}{l}73 \text { IDELR } \uparrow 84 \\
(\mathrm{~Pa} . \mathrm{SEA} 2018)\end{array}$ & FAPE & $\mathrm{S}$ & 3,4-placement; marginal case - many disabilities \\
\hline N.Y.C. Dep’t of Educ. & $\begin{array}{l}119 \text { LRP } 1573 \\
(\text { N.Y. SEA } 2018)^{R O}\end{array}$ & Adjudicative & $\mathrm{S}$ & 3,4-stay-put \\
\hline N.Y.C. Dep’t of Educ. & $\begin{array}{l}119 \text { LRP } 4663 \\
(\text { N.Y. SEA 2019) }\end{array}$ & Adjudicative & $\mathrm{S}$ & 3.4-stay-put \\
\hline RSU \#31/M.S.A.D. \#31 & $\begin{array}{l}119 \text { LRP } 12193 \\
\text { (Me. SEA 2019) }\end{array}$ & FAPE & $\mathrm{P}$ & $\begin{array}{l}\text { 3,4-child find violation } \rightarrow \text { partial compensatory ed. } \\
\text { services }\end{array}$ \\
\hline S. Orange Cent. Sch. & 119 LRP 15955 & FAPE & $\mathrm{S}^{*}$ & 3,4-limited exception of compensatory ed. for \\
\hline
\end{tabular}




\begin{tabular}{|c|c|c|c|c|}
\hline Dist. & (N.Y. SEA 2019) & & & missed counseling sessions \\
\hline $\begin{array}{l}\text { San Leandro Unified } \\
\text { Sch. Dist. }\end{array}$ & $\begin{array}{l}119 \text { LRP } 18039 \\
\text { (Cal. SEA 2019) }\end{array}$ & Remedies & $\mathrm{S}$ & $\begin{array}{l}\text { 3,4-district's evaluation was appropriate - thus, } \\
\text { denied IEE at public expense }\end{array}$ \\
\hline $\begin{array}{l}\text { Cornerstone Charter } \\
\text { Acad., Inc. }\end{array}$ & $\begin{array}{l}119 \text { LRP } 22538 \\
\text { (N.C. SEA 2019) }\end{array}$ & Identification & $\mathrm{S}$ & $\begin{array}{l}\text { 3-child find; 4-lack of evidence for both TBI and } \\
\text { special ed. need }\end{array}$ \\
\hline \multicolumn{5}{|c|}{ Court Decisions $(n=29)$} \\
\hline $\begin{array}{l}\text { R.B. v. N.Y.C. Dep't of } \\
\text { Educ. }\end{array}$ & $\begin{array}{l}57 \text { IDELR } \uparrow 155 \\
\text { (S.D.N.Y. 2011) }\end{array}$ & Adjudicative & $\mathrm{S}$ & $\begin{array}{l}\text { 3,4-statute of limitations (reversing tuition } \\
\text { reimbursement award) }\end{array}$ \\
\hline $\begin{array}{l}\text { N.P. v. E. Orange Bd. } \\
\text { of Educ. }\end{array}$ & $\begin{array}{l}56 \text { IDELR } ₫ 49 \\
\text { (D.N.J. 2011) }\end{array}$ & FAPE & $\mathrm{S}$ & 3,4-procedural violation w/o loss to student \\
\hline $\begin{array}{l}\text { M.B. v. Hamilton Se. } \\
\text { Sch. }\end{array}$ & $\begin{array}{l}688 \text { F.3d } 851 \\
(7 \text { th Cir. 2011) }\end{array}$ & FAPE & $\mathrm{S}$ & 3,4-substantive FAPE \\
\hline Alt v. Shirey & $\begin{array}{l}2012 \text { WL } 726579, \\
\text { adopted, } 2012 \mathrm{WL} \\
726593 \\
\text { W.D. Pa. 2012) }\end{array}$ & $\begin{array}{l}\S 504 / \mathrm{ADA} \\
(\mathrm{FAPE})\end{array}$ & Inc. & $\begin{array}{l}\text { 3,4-denied dismissal of failure-to-accommodate } \\
\text { claim (marginal - incidental to various other liability } \\
\text { claims) }\end{array}$ \\
\hline $\begin{array}{l}\text { G.J. v. Muscogee Cty. } \\
\text { Sch. Dist. }\end{array}$ & $\begin{array}{l}688 \text { F.3d } 1258 \\
\text { (11th Cir. 2012) }\end{array}$ & Misc. & $\mathrm{S}$ & $\begin{array}{l}\text { 3,4-consent for reevaluation - extensive conditions } \\
\text { amounted to effective refusal }\end{array}$ \\
\hline \multirow[t]{2}{*}{ J.R. v. Cox-Cruey } & $\begin{array}{l}61 \text { IDELR \ } 212 \\
\text { (E.D. Ky. 2013) }\end{array}$ & Adjudicative & $\mathrm{S}$ & $\begin{array}{l}\text { 3,4-stay-put: student aged out (and also untimely } \\
\text { appeal to second tier - } 65 \text { IDELR } 9294 \text { (E.D. Ky. } \\
\text { 2015)) }\end{array}$ \\
\hline & $\begin{array}{l}65 \text { IDELR \ } 294 \\
\text { (E.D. Ky. 2015) }\end{array}$ & Adjudicative & $\mathrm{S}^{*}$ & 3,4-failure to exhaust (untimely at second tier) \\
\hline $\begin{array}{l}\text { Street v. District of } \\
\text { Columbia }\end{array}$ & $\begin{array}{l}64 \text { IDELR } 1140 \\
\text { (D.D.C. 2014) }\end{array}$ & $\begin{array}{l}\S 504 / \mathrm{ADA}^{\mathrm{DC}} \\
\text { (Adjudicative) }\end{array}$ & Inc. & 3,4 -failure to exhaust \\
\hline $\begin{array}{l}\text { Coleman v. Pottstown } \\
\text { Sch. Dist. }\end{array}$ & $\begin{array}{l}\text { 581 F.App'x } 141 \\
\text { (3d Cir. 2014) }\end{array}$ & FAPE & $\mathrm{S}$ & marginal (one of many disabilities) \\
\hline Ripple v. Marble Falls & 99 F. Supp. 3d 662 & $\S 504 / \mathrm{ADA}$ & $\mathrm{S}$ & 3,4-return to play concussion case - lack of requisite \\
\hline
\end{tabular}




\begin{tabular}{|c|c|c|c|c|}
\hline Indep. Sch. Dist. & (W.D. Tex. 2015) & (Misc.) & & bad faith or gross misjudgment \\
\hline $\begin{array}{l}\text { L.M. v. Downingtown } \\
\text { Area Sch. Dist. }\end{array}$ & $\begin{array}{l}65 \text { IDELR } \uparrow 124 \\
\text { (E.D. Pa. 2015) }\end{array}$ & FAPE & $\mathrm{S}$ & marginal (largely other conditions) \\
\hline $\begin{array}{l}\text { Doe v. Bd. of Educ. of } \\
\text { Washington Cty. }\end{array}$ & $\begin{array}{l}66 \text { IDELR } \uparrow 5 \\
(\mathrm{D} . \mathrm{Md} .2015)\end{array}$ & $\begin{array}{l}\S 504 / \mathrm{ADA}^{\mathrm{DC}} \\
\text { (Adjudicative) }\end{array}$ & Inc. & 3,4-no need to exhaust \\
\hline \multirow[t]{2}{*}{$\begin{array}{l}\text { Perrin v. Warrior Run } \\
\text { Sch. Dist. }\end{array}$} & \multirow{2}{*}{ 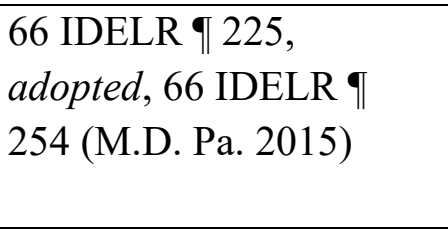 } & Identification & $\mathrm{S}$ & $\begin{array}{l}\text { 3,4-including child find and evaluation - two } \\
\text { concussions }\end{array}$ \\
\hline & & $\begin{array}{l}\S 504 / \mathrm{ADA} \\
\text { (Elig.) }\end{array}$ & $\mathrm{S}$ & $\begin{array}{l}\text { 3,4-even assuming arguendo elig., lack of requisite } \\
\text { intent }\end{array}$ \\
\hline \multirow{4}{*}{$\begin{array}{l}\text { A.L. v. Jackson Cty. } \\
\text { Sch. Bd. }\end{array}$} & \multirow{3}{*}{$\begin{array}{l}635 \text { F. App'x } 774 \\
\text { (11th Cir. 2015) }\end{array}$} & FAPE & $\mathrm{S}$ & 3,4-lack of participation attributable to parent \\
\hline & & Remedies & $\mathrm{S}$ & 3,4-IEE reimb.-parent exceeded reasonable limits \\
\hline & & $\begin{array}{l}\S 504 \\
\text { (Adjudicative) }^{\mathrm{DC}}\end{array}$ & $\mathrm{S}$ & 3,4-jurisdiction (e.g., exhaustion, waiver) \\
\hline & $\begin{array}{l}652 \text { F. App’x } 795 \\
\text { (11th Cir. 2016) }\end{array}$ & Adjudicative & $\mathrm{P}$ & $\begin{array}{l}\text { 3,4-Rule } 11 \text { sanctions against } P \text { reversed due to lack } \\
\text { of frivolousness ( } 2015 \text { FAPE ruling for S-above) }\end{array}$ \\
\hline $\begin{array}{l}\text { G.W. v. Boulder Valley } \\
\text { Sch. Dist. }\end{array}$ & $\begin{array}{l}67 \text { IDELR } \uparrow 112 \\
\text { (D. Colo. 2016) }\end{array}$ & Adjudicative & $\mathrm{S}$ & $\begin{array}{l}\text { 3-stay-put; 4-IEP specified out-of-state residential } \\
\text { placement (despite mother's preference for in-state) }\end{array}$ \\
\hline $\begin{array}{l}\text { Ricci v. Beech Grove } \\
\text { City Sch. }\end{array}$ & $\begin{array}{l}68 \text { IDELR } \ 67 \\
\text { (S.D. Ind. 2016) }\end{array}$ & FAPE & $\mathrm{S}^{*}$ & $\begin{array}{l}\text { 4-but ordered tuition reimbursement for stay-put } \\
\text { period }\end{array}$ \\
\hline $\begin{array}{l}\text { C.S. v. Montclair Bd. of } \\
\text { Educ. }\end{array}$ & $\begin{array}{l}70 \text { IDELR ๆ } 206 \\
\text { (D.N.J. 2017) }\end{array}$ & FAPE & $\mathrm{S}$ & $\begin{array}{l}\text { 3-procedural \& substantive; 4-denied tuition } \\
\text { reimbursement }\end{array}$ \\
\hline $\begin{array}{l}\text { Doe v. Pleasant Valley } \\
\text { Sch. Dist. }\end{array}$ & $\begin{array}{l}119 \text { LRP } 364 \text { (S.D. Iowa } \\
\text { 2017), aff'd mem., } 745 \text { F. } \\
\text { App'x } 658 \text { (8th Cir. } \\
\text { 2018) }\end{array}$ & $\S 504(\mathrm{FAPE})^{\mathrm{DC}}$ & $\mathrm{S}$ & $\begin{array}{l}\text { 3,4-failure to follow IEE does not constitute requisite } \\
\text { gross misjudgment or bad faith }\end{array}$ \\
\hline \multirow{2}{*}{$\begin{array}{l}\text { Lincoln-Sudbury Reg'l } \\
\text { Sch. Dist. v. Mr. W }\end{array}$} & \multirow{2}{*}{$\begin{array}{l}71 \text { IDELR } \uparrow 153 \\
\text { (D. Mass. 2018) }\end{array}$} & Identification & $\mathrm{S}$ & 3-incl. child find (and parallel state law) - concussion \\
\hline & & $\S 504 /$ ADA(Elig.) & $\mathrm{S}$ & 3-elig. (duration-concussion) \\
\hline M.N. v. Sch. Bd. of & 71 IDELR $₫ 170$ & FAPE & $\mathrm{P}$ & 3,4-multiple disabilities-marginal \\
\hline
\end{tabular}




\begin{tabular}{|c|c|c|c|c|}
\hline City of Va. Beach & (E.D. Va. 2018) & Remedies & $\mathrm{P}$ & 3,4-tuition reimbursement - two years and stay-put \\
\hline $\begin{array}{l}\text { Trujillo v. Sacramento } \\
\text { Unified Sch. Dist. }\end{array}$ & $\begin{array}{l}71 \text { IDELR } \uparrow 213 \\
\text { (C.D. Cal. 2018) }\end{array}$ & $\begin{array}{l}\S 504 / \mathrm{ADA} \\
\left(_{(\text {Misc. }}\right)^{\mathrm{DC}}\end{array}$ & $\mathrm{S}$ & 3,4-retaliation \\
\hline $\begin{array}{l}\text { Doe v. City of New } \\
\text { Bedford }\end{array}$ & $\begin{array}{l}72 \text { IDELR } \ 18 \\
\text { (D. Mass. 2018) }\end{array}$ & $\begin{array}{l}\S 504 / \mathrm{ADA} \\
\text { (Misc.) }^{\mathrm{DC}}\end{array}$ & $\mathrm{S}$ & 3,4 -settlement agreement release \\
\hline $\begin{array}{l}\text { Tveter v. Derry } \\
\text { Cooperative Sch. Dist. }\end{array}$ & $\begin{array}{l}72 \text { IDELR } ₫ 149 \\
\text { (D.N.H. 2018) }\end{array}$ & $\begin{array}{l}\S 504 / \mathrm{ADA} \\
\text { (Adjudicative) }^{\mathrm{DC}}\end{array}$ & Inc. & $\begin{array}{l}\text { 3,4-failure to exhaust; 4-possible liability of private } \\
\text { school, not school district }\end{array}$ \\
\hline $\begin{array}{l}\text { Tuttle v. Cent. Kitsap } \\
\text { Sch. Dist. }\end{array}$ & $\begin{array}{l}72 \text { IDELR } \uparrow 242 \\
\text { (W.D. Wash. 2018) }\end{array}$ & Adjudicative & Inc. & $\begin{array}{l}\text { 3,4-denied district's motion of summary judgment re } \\
\text { enforcement of settlement agreement }\end{array}$ \\
\hline $\begin{array}{l}\text { PlainsCapital Bank v. } \\
\text { Keller Indep. Sch. Dist. }\end{array}$ & $\begin{array}{l}\text { 746 F. App'x } 355 \\
\text { (5th Cir. 2018) }\end{array}$ & $\begin{array}{l}\S 504 / \mathrm{ADA} \\
(\mathrm{FAPE})^{\mathrm{DC}}\end{array}$ & $\mathrm{S}$ & $\begin{array}{l}\text { 3,4-lack of deliberate indifference (suicide liability } \\
\text { case) }\end{array}$ \\
\hline $\begin{array}{l}\text { Carr v. New Glarus } \\
\text { Sch. Dist. }\end{array}$ & $\begin{array}{l}73 \text { IDELR } 936 \\
\text { (W.D. Wis. 2018) }\end{array}$ & FAPE & $\mathrm{S}$ & $\begin{array}{l}\text { 3-including implementation issues; 4-denied reimb. } \\
\text { for college calculus course (including untimely } \\
\text { request) }\end{array}$ \\
\hline \multirow[t]{2}{*}{$\begin{array}{l}\text { A.C. v. Capistrano } \\
\text { Unified Sch. Dist. }\end{array}$} & \multirow[t]{2}{*}{$\begin{array}{l}73 \text { IDELR } 994 \\
\text { (C.D. Cal. 2018) }\end{array}$} & FAPE & $\mathrm{S}^{*}$ & $\begin{array}{l}\text { 3,4-effect limited to attorneys' fees and prospective } \\
\text { placement due to stay-put for tuition reimbursement }\end{array}$ \\
\hline & & Remedies & $\mathrm{P}$ & $\begin{array}{l}\text { 3,4-transportation reimb. (via stay-put) - subject to } \\
\text { records }\end{array}$ \\
\hline $\begin{array}{l}\text { Dennis v. Lubbock- } \\
\text { Cooper Indep. Sch. } \\
\text { Dist. }\end{array}$ & $\begin{array}{l}\text { 74 IDELR \ } 18 \\
\text { (N.D. Tex. 2019) }\end{array}$ & FAPE & $\mathrm{S}^{*}$ & $\begin{array}{l}\text { 3-Endrew } F \text {; 4-but reimbursement of IEE } \\
\text { (incidental) }\end{array}$ \\
\hline $\begin{array}{l}\text { Ventura de Paulino v. } \\
\text { N.Y.C. Dep't of Educ. }\end{array}$ & $\begin{array}{l}\text { 74 IDELR \ } 40 \\
\text { (S.D.N.Y. 2019) }\end{array}$ & Adjudicative & $\mathrm{S}$ & 3-stay-put \\
\hline \multirow{2}{*}{$\begin{array}{l}\text { Morales v. Newport- } \\
\text { Mesa Unified Sch. Dist. }\end{array}$} & \multirow{2}{*}{$\begin{array}{l}768 \text { F. App'x } 717 \\
\text { (9th Cir. 2019) }\end{array}$} & Remedies & $\mathrm{S}$ & 3-limited compensatory ed. (child find/FAPE) \\
\hline & & $\begin{array}{l}\S 504 / \mathrm{ADA} \\
(\mathrm{FAPE})\end{array}$ & $\mathrm{S}$ & 3,4-lack of deliberate indifference \\
\hline
\end{tabular}

Vote: ${ }^{\mathrm{DC}}=$ double-covered (i.e., $§ 504$ claim for student with IEP); ${ }^{\mathrm{RO}}=$ review officer decision; ${ }^{*}=$ qualified (i.e., semi-intermediate) rulings; acronyms:

$\mathrm{IDD}=$ attention deficit disorder; $\mathrm{AT}=$ assistive technology; $\mathrm{ED}=$ emotional disturbance; $\mathrm{ESY}=$ extended school year; FAPE=free appropriate public education; 
$\mathrm{TI}=$ failure to implement; IEE=independent educational evaluation; IEP=individualized education program; LRE=least restrictive environment; $\mathrm{OHI}=\mathrm{other}$ ealth impairment; SLD=specific learning disability. 


\section{DPHMD Executive Board Members}

\section{Officers}

President (RA Rep; IDC Rep): Laura Clarke

President-Elect (RA Rep): Robbie Hampton

Vice President: Denise Griffin

Immediate Past President (IDC Rep): Angie Juárez

Secretary: Alyssa Marcum

Treasurer: Meg Cooper

\section{Coordinators}

Children and Youth Action Network (CAN) Coordinator: Laura Clarke

\section{Publication Editors}

Journal Editor: Dusty Columbia Embury

Newsletter Editor: Angie Juárez

\section{Committee Chairs \& Representatives}

Awards Committee: Angie Juárez

Bylaws Committee: Mari Beth Coleman

Chronic Medical Conditions Committee: Kelly Ihejiawu and Beth Stuchell

Communications and Social Media Committee: Cate Smith

Finance Committee: Meg Cooper

Knowledge and Skills Committee: Joni Baldwin

Membership Committee: Allison Kroesch and Krystal Carrillo

Nominations Committee: Angie Juárez

Professional Development Committee: Sean Murphy

Publications Committee: Dusty Columbia Embury

Severe and Multiple Disabilities Committee: Alyssa Marcum

Student Representative: Jennifer Cook

Representative Assembly Reps (president and president-elect): Laura Clarke and Robbie Hampton

Interdivisional Caucus Reps (president and immediate past-president): Laura Clarke and Angie Juárez 